Old Dominion University

ODU Digital Commons

\title{
Riverine Carbon Cycling Over The Past Century in the Mid-Atlantic Region of the United States
}

\author{
Yuanzi Yao \\ Hanqin Tian \\ Shufen Pan \\ Raymond G. Najjar \\ Marjorie A.M. Friedrichs
}

See next page for additional authors

Follow this and additional works at: https://digitalcommons.odu.edu/ccpo_pubs

Part of the Climate Commons, and the Oceanography Commons

\section{Original Publication Citation}

Yao, Y., Tian, H., Pan, S., Najjar, R. G., Friedrichs, M. A. M., Bian, Z., ... Hofmann, E. E. (2021). Riverine carbon cycling over the past century in the Mid-Atlantic region of the United States. Journal of Geophysical Research: Biogeosciences, 126(5), Article e2020JG005968, 1-22. 


\section{Authors}

Yuanzi Yao, Hanqin Tian, Shufen Pan, Raymond G. Najjar, Marjorie A.M. Friedrichs, Zihao Bian, Hong-Yi Li, and Eileen E. Hofmann 


\section{JGR Biogeosciences}

\author{
RESEARCH ARTICLE \\ 10.1029/2020JG005968 \\ Key Points: \\ - Riverine carbon fluxes show twofold \\ increase in standard deviation \\ resulting from increased climate \\ variability \\ - Climate variability explains most of \\ the interdecadal change in riverine \\ carbon export to the coastal ocean in \\ the US Mid-Atlantic watersheds \\ - At the same time, land conversion \\ from cropland to impervious \\ surfaces and forest has decreased \\ carbon export to the coastal ocean
}

Supporting Information:

Supporting Information may be found in the online version of this article.

Correspondence to:

H. Tian,

tianhan@auburn.edu

Citation:

Yao, Y., Tian, H., Pan, S., Najjar, R. G., Friedrichs, M. A. M., Bian, Z., et al. (2021). Riverine carbon cycling over the past century in the Mid-Atlantic region of the United States. Journal of Geophysical Research: Biogeosciences, 126, e2020JG005968. https://doi. org/10.1029/2020JG005968

Received 12 JUL 2020 Accepted 19 APR 2021

Author Contributions:

Conceptualization: Yuanzi Yao, Hanqin Tian

Data curation: Yuanzi Yao, Hanqin Tian

Formal analysis: Yuanzi Yao Funding acquisition: Hanqin Tian, Shufen Pan, Raymond G. Najjar, Marjorie A. M. Friedrichs, Eileen E. Hofmann

Investigation: Yuanzi Yao

Methodology: Yuanzi Yao

Project Administration: Hanqin

Tian, Shufen Pan, Marjorie A. M.

Friedrichs, Eileen E. Hofmann

Resources: Yuanzi Yao, Hanqin Tian

Software: Yuanzi Yao

Supervision: Hanqin Tian, Raymond

G. Najjar, Marjorie A. M. Friedrichs,

Hong-Yi Li

(C) 2021. American Geophysical Union. All Rights Reserved.

\section{Riverine Carbon Cycling Over the Past Century in the Mid-Atlantic Region of the United States}

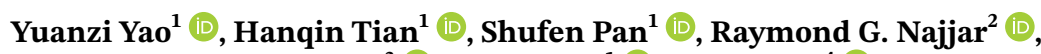

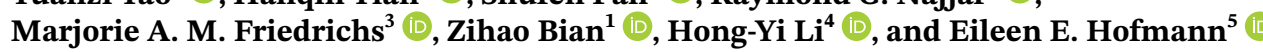

${ }^{1}$ International Center for Climate and Global Change Research and School of Forestry and Wildlife Sciences, Auburn University, Auburn, AL, USA, ${ }^{2}$ Department of Meteorology and Atmospheric Science, The Pennsylvania State University, University Park, PA, USA, ${ }^{3}$ Virginia Institute of Marine Science, William \& Mary, Gloucester Point, VA, USA, ${ }^{4}$ Department of Civil and Environmental Engineering, Cullen College of Engineering, University of Houston, Houston, TX, USA, ${ }^{5}$ Department of Ocean, Earth and Atmospheric Sciences, Center for Coastal Physical Oceanography, Old Dominion University, Norfolk, VA, USA

Abstract The lateral transport and degassing of carbon in riverine ecosystems is difficult to quantify on large spatial and long temporal scales due to the relatively poor representation of carbon processes in many models. Here, we coupled a scale-adaptive hydrological model with the Dynamic Land Ecosystem Model to simulate key riverine carbon processes across the Chesapeake and Delaware Bay Watersheds from 1900 to 2015. Our results suggest that throughout this time period riverine $\mathrm{CO}_{2}$ degassing and lateral dissolved inorganic carbon fluxes to the coastal ocean contribute nearly equally to the total riverine carbon outputs (mean \pm standard deviation: $886 \pm 177 \mathrm{Gg} \mathrm{C} \cdot \mathrm{yr}^{-1}$ and $883 \pm 268 \mathrm{Gg} \mathrm{C} \cdot \mathrm{yr}^{-1}$, respectively). Following in order of decreasing importance are the lateral dissolved organic carbon flux to the coastal ocean $\left(293 \pm 81 \mathrm{Gg} \mathrm{C} \cdot \mathrm{yr}^{-1}\right)$, carbon burial $\left(118 \pm 32 \mathrm{Gg} \mathrm{C} \cdot \mathrm{yr}^{-1}\right)$, and lateral particulate organic carbon flux $\left(105 \pm 35 \mathrm{Gg} \mathrm{C} \cdot \mathrm{yr}^{-1}\right)$. In the early $2000 \mathrm{~s}$, carbon export to the coastal ocean from both the Chesapeake and Delaware Bay watersheds was only 15\%-20\% higher than it was in the early 1900s (decade), but it showed a twofold increase in standard deviation. Climate variability (changes in temperature and precipitation) explains most $\left(225 \mathrm{Gg} \mathrm{C} \cdot \mathrm{yr}^{-1}\right)$ of the increase since 1900 , followed by changes in atmospheric $\mathrm{CO}_{2}(82 \mathrm{Gg}$ $\left.\mathrm{C} \cdot \mathrm{yr}^{-1}\right)$, atmospheric nitrogen deposition $\left(44 \mathrm{Gg} \mathrm{C} \cdot \mathrm{yr}^{-1}\right)$, and applications of nitrogen fertilizer and

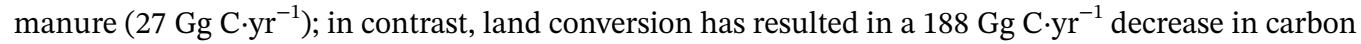
export.

Plain Language Summary Rivers are an important component of the terrestrial-aquatic ocean continuum as they serve as a conduit for transporting carbon from the land to the coastal ocean. It is essential to track the fate of this carbon, including how much carbon is buried in the riverbed, outgassed to the atmosphere, and exported to the ocean. However, it is often difficult to quantify these carbon transport processes on the watershed scale because observational data obtained by field surveys can only be used to estimate the magnitude of these processes at distinct points. In this study, we used a coupled terrestrial-aquatic ecosystem model to assess the century-long full carbon budget of the riverine ecosystem across the watersheds of Chesapeake Bay and Delaware Bay. In addition, we examined the individual and combined impacts of climate change and anthropogenic activities on these terrestrial ecosystems and the resultant $\mathrm{CO}_{2}$ emissions of their associated rivers. We found that climate variability and land conversion (from cropland to impervious surfaces and forest) are the most important factors governing the long-term change in riverine carbon dynamics. We also highlighted the importance of riverine $\mathrm{CO}_{2}$ emissions in the overall regional carbon budget.

\section{Introduction}

Rivers and streams, which are part of the terrestrial-aquatic ocean continuum (Regnier et al., 2013), bridge the two largest active carbon reservoirs: terrestrial and marine ecosystems. Lateral carbon fluxes through river channels to the ocean and $\mathrm{CO}_{2}$ release to the atmosphere from rivers are now known to be much larger than previously thought (Regnier et al., 2014). Specifically, updated estimates of riverine carbon fluxes have resulted in substantial revisions in carbon accounting over regions like the conterminous U.S. and the Amazon River basin (Butman et al., 2016; Hastie et al., 2019). Terrestrial carbon loading from land into rivers 
Validation: Yuanzi Yao, Zihao Bian Visualization: Yuanzi Yao Writing - original draft: Yuanzi Yao, Hanqin Tian

Writing - review \& editing: Hanqin Tian, Shufen Pan, Raymond G. Najjar, Marjorie A. M. Friedrichs, Hong-Yi Li (hereafter "terrestrial carbon loading"), is the dominant component of the carbon budget of inland waters (McDonald et al., 2013),but its magnitude is poorly constrained (Drake et al., 2018). Moreover, riverine carbon processes such as carbon export from rivers to the coastal ocean, carbon burial in sediments, and long-term riverine $\mathrm{CO}_{2}$ degassing at large scales remain poorly quantified. To develop a better constrained riverine carbon budget, therefore, it is of critical importance to understand and quantify the key components of riverine carbon cycling in the context of multiple environmental changes (Regnier et al., 2013).

Data-based analyses have been conducted at regional and continental levels to quantify the carbon fluxes from rivers. However, none of these studies quantify the temporal variability of carbon fluxes from rivers across large spatial scales (Butman \& Raymond, 2011; Butman et al., 2016; Raymond et al., 2013). Regression-based tools, such as Load Estimator (LOADEST; Runkel et al., 2004) and spatially referenced regression on watershed attributes (Georghiades, 2003), have been widely deployed to reconstruct the spatial and temporal patterns of riverine carbon fluxes. However, due to the empirical basis of such regression-based methods, they are limited in their ability to attribute the impacts of environmental factors on terrestrial-aquatic carbon dynamics, which limits their usefulness for policy-relevant attribution studies.

The impacts of climate change and human disturbances on riverine carbon dynamics have only become apparent during the past couple of decades (Regnier et al., 2013). Increased exports of dissolved organic carbon (DOC) and dissolved inorganic carbon (DIC) have been found to be primarily due to the long-term increase in air temperature (Laudon et al., 2012; Pastor et al., 2003), since precipitation and the associated hydrological response of the watershed play critical roles in regulating carbon export (Raymond \& Oh, 2007). Human activities have also substantially influenced the terrestrial carbon cycle, resulting in significant impacts on the aquatic carbon cycle (Raymond \& Hamilton, 2018). For example, land conversion from organic-rich soils during World War II substantially increased soil carbon loss into rivers (Noacco et al., 2017). Unexpected anthropogenic effects, including $\mathrm{CO}_{2}$ fertilization and enhanced atmospheric nitrogen deposition, led to an increase in carbon loading to rivers (Findlay, 2005; Houghton, 2010). In addition to terrestrial carbon loading, other factors, such as changes in freshwater discharge and water temperature, help to regulate riverine carbon dynamics (Chapra, 2008; Harrison et al., 2009; Isaak et al., 2016) and their impacts on downstream waters.

Recent mechanistic understanding of terrestrial and aquatic carbon dynamics from fieldwork has spurred substantial progress in process-based modeling (Dick et al., 2015; Laruelle et al., 2017; Seitzinger et al., 2005; Tian, Yang, et al., 2015), which can help fill temporal and spatial data gaps. However, Earth System Models (ESMs) are limited by their lack of integration between land and ocean systems through riverine carbon flow along the land-ocean continuum (Bauer et al., 2013). Additionally, most ESMs are applied at coarse spatial resolution, and thus, the surface and subsurface hydrodynamics are overly simplified, the coastline is not well resolved, and headwater streams (first-third stream order) are excluded due to their small area (McClain et al., 2003) and structural complexity (Battin et al., 2009).

Despite not being included in ESMs, there is increasing recognition of headwater streams as hotspots (McClain et al., 2003) of riverine $\mathrm{CO}_{2}$ degassing (Battin et al., 2009). Recent studies indicate that most degassing is from these streams (Butman \& Raymond, 2011; Butman et al., 2016; Raymond et al., 2013). Additionally, headwater streams and floodplains store most of the riverine carbon and far more than previously thought (Beckman \& Wohl, 2014; Wohl et al., 2012), and thus, they must be included in process-based models to study carbon cycling at the terrestrial-aquatic interface.

To better understand the roles of riverine $\mathrm{CO}_{2}$ emissions and lateral carbon fluxes in the carbon cycle at the terrestrial-aquatic interface, we coupled a scale-adaptive river routing scheme (MOdel of Scale-Adaptive River Transport [MOSART]; Li et al., 2013) with the Dynamic Land Ecosystem Model (DLEM, Tian, Yang, et al., 2015). To test the performance of our newly improved terrestrial-aquatic interface module within the DLEM framework, we applied the model to the watersheds of Chesapeake Bay and Delaware Bay, two large estuaries located in the Mid-Atlantic United States (US, Figure 1). Major rivers draining into the Chesapeake Bay include the Susquehanna River, Potomac River, James River, Rappahannock River, and York River. The Chesapeake Bay Watershed (CBW) and Delaware Bay Watershed (DBW) have areas of 166,530 and $33,151 \mathrm{~km}^{2}$, respectively. These two watersheds, which together have a current population of 25.5 million, 


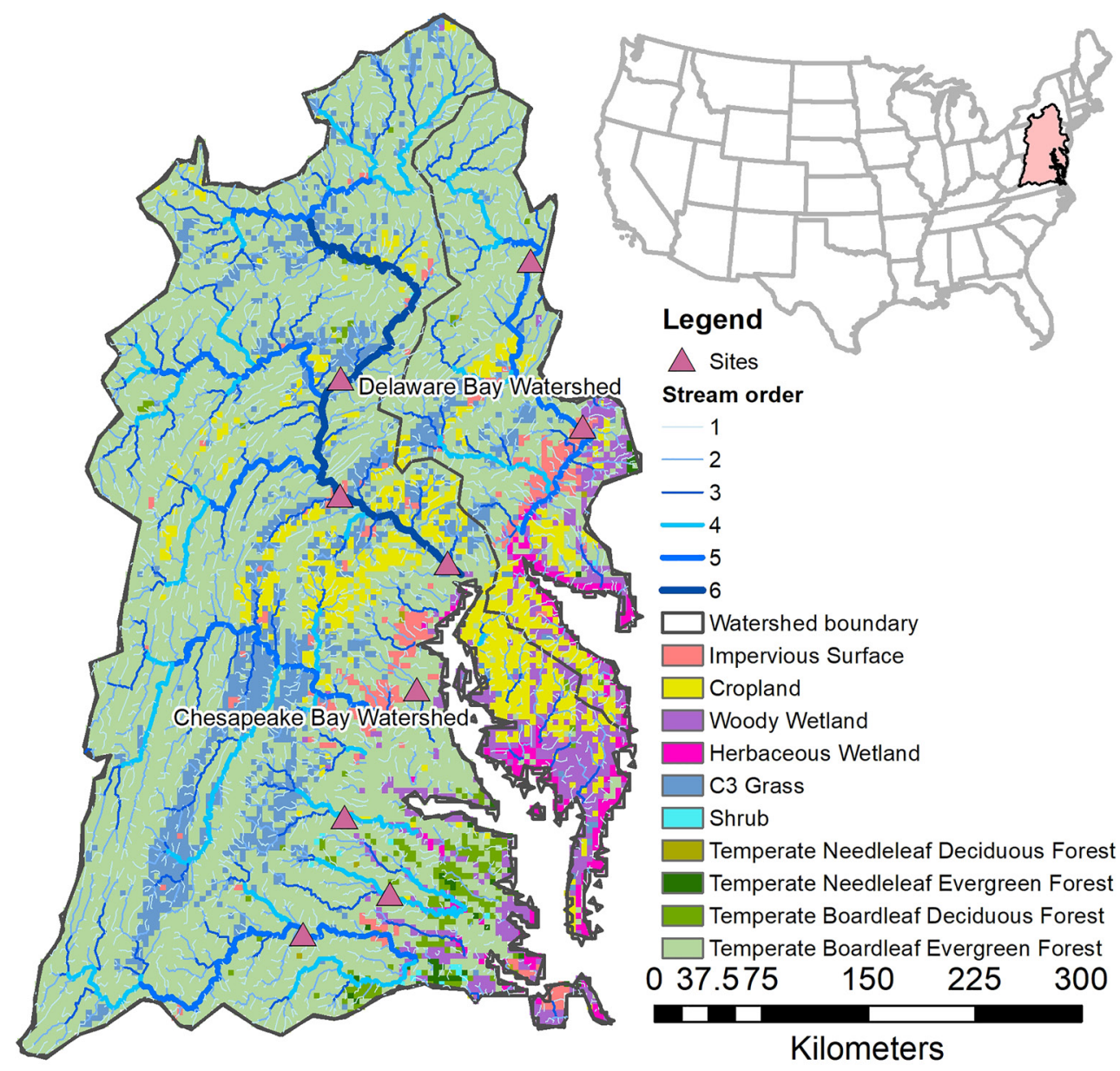

Figure 1. Major plant functional types, land cover, and stream orders in the Chesapeake and Delaware Bay Watersheds. Also shown (pink triangles) are sites where DLEM riverine carbon transport is evaluated with observations. DLEM, Dynamic Land Ecosystem Model.

are located in the most urbanized area of the US and have thus been subjected to massive land conversion during the last century (Jantz et al., 2005).

In this study, we quantify the magnitude and spatial patterns of riverine $\mathrm{CO}_{2}$ degassing, carbon burial, and the lateral fluxes of particulate organic carbon (POC), DOC, and DIC in the CBW and DBW from 1900 to 2015. Furthermore, we quantitatively attribute the variability in riverine carbon fluxes in these watersheds to multiple environmental factors.

\section{Methodology: Model Improvement}

\subsection{DLEM-Terrestrial/Aquatic Interface Module}

The land component of DLEM 2.0 (Tian, Yang, et al., 2015) and a scale-adaptive river transport scheme (Li et al., 2013) were incorporated into the DLEM framework as the terrestrial/aquatic interface module. Here, scale adaptive means the routing processes within and between the latitude/longitude grid cells are based on the same set of governing equations and adaptive parameterization strategy so that, when spatial resolution changes, the simulated water fluxes (particularly in the headwater streams) do not change significantly.

\subsubsection{The Land Component of DLEM 2.0}

This is a process-based terrestrial ecosystem model that simulates water, carbon, and nitrogen fluxes, including the emissions of greenhouse gases $\left(\mathrm{CO}_{2}, \mathrm{CH}_{4}\right.$, and $\left.\mathrm{N}_{2} \mathrm{O}\right)$ in terrestrial ecosystems (Tian et al., 2012). 


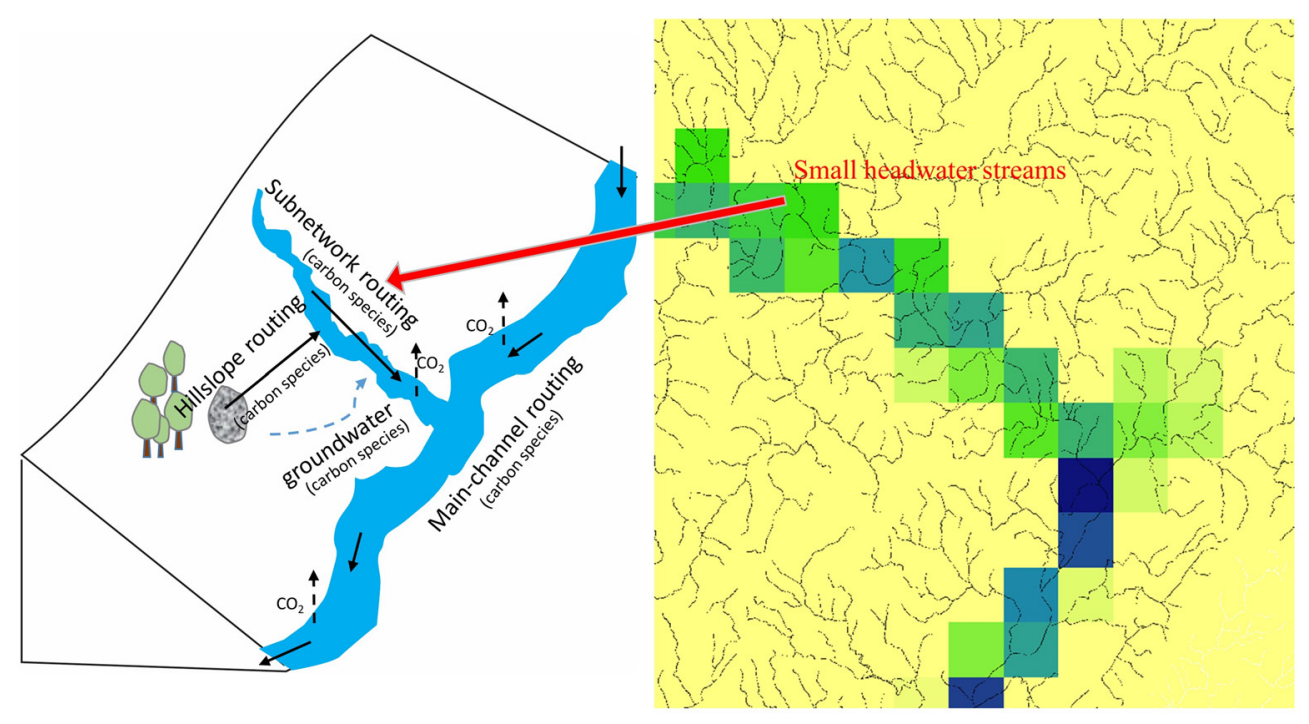

Figure 2. The concept model of the scale-adaptive water transport model and the representation of small rivers within the water transport framework.

To address subgrid terrestrial processes, DLEM utilizes a land-use cohort structure as the basic unit, which aggregates four natural plant function types, one cropland type, and an urban impervious type into one grid cell (Liu \& Tian, 2010). The model simulates land carbon dynamics, including plant photosynthesis, and soil biogeochemical processes, and its response to climate change and land conversions (Tian et al., 2012). The outputs of carbon and nitrogen loading from the DLEM land module are utilized as the boundary condition to force the riverine biogeochemistry module (Tian, Yang, et al., 2015). In our previous studies, the DLEM has been carefully evaluated using observational data and then applied to quantify water discharge (Liu et al., 2013; Tao et al., 2014; Yang, Tian, Friedrichs, Liu, et al., 2015), riverine carbon exports (Ren et al., 2015; Tian, Yang, et al., 2015), and riverine nitrogen export (Pan, Bian, Tian, Yao et al., 2021; Yang, Tian, Friedrichs, Hopkinson, et al., 2015).

The DLEM 2.0 used the Linear Reservoir Routing (LLR) method to calculate river routing at the continental scale (Coe, 1998; Liu et al., 2013; Tian, Yang, et al., 2015). The LLR method used an empirical equation based on the channel slope to calculate the constant flow velocity at each grid cell. However, the run-off processes are nonlinear and dynamic. Thus, the LLR method is problematic in predicting the temporal pattern (monthly and daily level in this study) of water discharge (Chow, 1964; Li et al., 2013; Yamazaki et al., 2011). Accordingly, we updated the channel routing module within the DLEM 2.0 in this study.

\subsubsection{Scale-Adaptive Water Transport Scheme}

In this study, a scale-adaptive and fully physically based model named MOSART (Li et al., 2013, 2015; Figure 2) was incorporated into the DLEM. The MOSART separates the water transport within the grid cells into three subgrid processes: hillslope routing, subnetwork routing, and main channel routing. The water from surface runoff is first routed across the hillslopes. The subnetwork channels receive the water from the hillslope flow and the groundwater discharge and flows into the main channel. The main channel receives water from upstream grid cells and local subnetworks and discharges to the downstream grid cell. All three subgrid routing processes use kinematic wave methods (Chow, 1964) which require several river-network related parameters (e.g., flow direction, channel length, and channel slope) and geomorphological parameters (e.g., channel width and channel depth). The river-network related parameters (flow direction, channel length, and channel slope) were derived from a fine-resolution hydrography data set using a dominant river tracing algorithm so that the important river network features such as the upstream drainage area and the cumulative flow distance (e.g., from a headwater grid cell to a downstream grid cell) are preserved consistently across various spatial resolutions (Wu et al., 2012). The geomorphological parameters can be derived using empirical hydraulic geometry relationships (Li et al., 2013, 2015) or remotesensing-based water surface extent data (Homer et al., 2015; Yamazaki et al., 2014). Similar to most land surface models, the DLEM 
only considers vertical movements of subsurface soil moisture and lumps the lateral groundwater transport with parameterized outflow rates from a groundwater pool to the local subnetworks.

The benefits gained from the scale-adaptive water transport scheme is that the lengths and topographic slopes of the hillslope are kept consistent and it is only necessary to adjust the subnetwork parameters with the spatial resolutions used (Li et al., 2013; Yao et al., 2020) (Figure 2). That is because the equivalent lengths of the subnetworks were calculated from all the tributaries within a grid cell beside the main channel, which gets longer (or shorter) as the grid size grows larger (or smaller). More detailed information can be found in the work of Li et al., (2013). Therefore, the physical parameters of the new water transport module only require minor recalibration during scale shifting. Another advancement of the MOSART model is that we can incorporate biogeochemical processes in small streams for large-scale analysis, which is similar to the previous global analysis (Wollheim et al., 2008).

Channel width is a critical parameter to represent the river water surface area. Empirical hydraulic geometry relationships are often derived from sparse ground-based measurements and contain nontrivial uncertainties when applied at the watershed or regional scales (Yamazaki et al., 2014). Here, we used remote sensing-based channel width data for the large river channels (Homer et al., 2015). However, the water surface areas of small rivers could not be well detected by remote sensing (Homer et al., 2015; Yamazaki et al., 2014). Hence, the channel width and water surface area of the small rivers are calculated based on a hydromorphic relationship derived for North America and New Zealand (Allen et al., 2018):

$$
\begin{gathered}
A_{s}=\left\{\begin{array}{cc}
A_{R S, \text { water }}, & \text { high - order stream } \\
W \times L, & \text { headwater stream }
\end{array}\right. \\
W=Q^{\frac{3}{5 r+3}} \times\left(0.5 A^{0.42}\right)^{\frac{r-1}{r+0.6}} \times\left(8.1(9.8 S)^{0.5} k^{-\frac{1}{6}} 14^{-\frac{5}{3}}\left(1-\frac{1}{r+1}\right)\right)^{-\frac{3}{5 r+3}}
\end{gathered}
$$

where $A_{s}$ is the surface area of the water body, $A_{R S \text {, water }}$ is the surface area derived from remote sensing data, $W(\mathrm{~m})$ and $L(\mathrm{~m})$ are the width and length of the rivers channel, respectively, $Q$ is the water discharge $\left(\mathrm{m}^{3} \cdot \mathrm{s}^{-1}\right), A$ is the upstream area (ha) of the subnetworks (here we assume it equals to the area of the grid cell), $S$ is the channel slope, and $r$ is a shape parameter set at 1.5 in this study. $k$ is a bed roughness length scale:

$$
k=\left(8.1(g)^{0.5} n\right)^{6}
$$

where $g$ is the gravity defined as $9.8 \mathrm{~m} \cdot \mathrm{s}^{2}$, and $n$ is the Gauckler-Manning friction coefficient which was set as $n=0.04 \mathrm{~m} \cdot \mathrm{s}^{-1}$. By using the methods for headwater stream, we can capture the dynamics of water surface area in response to a storm event. (Figure S3). It should be noted that since the hydrological component of the DLEM is fully distributed, the definitions of headwater stream, high-order stream, and stream orders may not be strictly consistent with other high-resolution (30-90 m) data analyses.

\subsection{Riverine Biogeochemical Processes}

The primary in-stream carbon processes include lateral transport, decomposition of organic matter, particle organic matter deposition, and $\mathrm{CO}_{2}$ degassing. These physical and biogeochemical processes have been adopted into the scale-adaptive water transport scheme. Specifically, this module can address the processes of headwater or small streams within a grid cell that were previously lacking investigation. The net fluxes of carbon species in the main channel and subnetwork are given by 


$$
\begin{gathered}
\frac{\Delta M_{P O C}}{\Delta t}=F_{a, P O C}-v_{s} A_{s} c_{P O C}-R_{P O C} M_{P O C} \\
\frac{\Delta M_{D O C}}{\Delta t}=F_{a, D O C}-R_{D O C} M_{D O C} \\
\frac{\Delta M_{D I C}}{\Delta t}=F_{a, D I C}+R_{P O C} M_{P O C}+R_{D O C} M_{D O C}-E_{C O 2}
\end{gathered}
$$

where $M_{P O C}, M_{D O C}$, and $M_{D I C}$, are the total mass of POC, DOC, and DIC, respectively, in the main channel or subnetworks (gC), $\Delta t$ is the time step (d), $F_{a}$ is the net advective transport of carbon species of the subnetwork and the main channel $\left(\mathrm{gC} \cdot \mathrm{d}^{-1}\right)$ (including inflow and outflow), $R_{D O C}$ and $R_{P O C}$ are the first order respiration rate coefficients $\left(\mathrm{d}^{-1}\right)$ of the organic carbon species, $v_{s}$ is the settling velocity of POC $\left(\mathrm{m} \cdot \mathrm{d}^{-1}\right)$, $C_{\mathrm{POC}}$ is the POC concentration $\left(\mathrm{gC} \cdot \mathrm{m}^{-3}\right)$, and $E_{\mathrm{CO} 2}$ is the evasion of $\mathrm{CO}_{2}$ to the atmosphere $\left(\mathrm{gC} \cdot \mathrm{d}^{-1}\right)$. In this study, we did not consider instream carbon sources or benthic respiration as well as the carbonate system in surface waters. We also assume that once a particle settles, it cannot be resuspended; it can only leave the system as respiration. Here, the hillslope flow receives carbon species from the land surface (with surface runoff) and contributes to the subnetwork flow (Figure 2). Carbon species (DOC, POC, and DIC) loadings from the land flow into the pools of hillslope flow and groundwater, and drain to subnetworks with no major changes (Figure 2). Biogeochemical processes within the hillslope flow and subsurface flow were not considered in the current model framework.

The advective fluxes of carbon through the subnetwork combine carbon inputs from both hillslope flow and subsurface flow:

$$
F_{a, \text { sub }}=F_{h / c}+F_{g / c}-Q_{\text {sub }} C_{\text {sub }}
$$

where $F_{h / c}$ is the carbon flux (DIC, DOC, or POC) $\left(\mathrm{gC} \mathrm{d}^{-1}\right)$ of the hillslope flow, $F_{g / c}$ is the carbon flux $\left(\mathrm{gC} \cdot \mathrm{d}^{-1}\right)$ from the groundwater pool to the subnetwork. Here, the hillslope flow and the groundwater pool receive carbon loadings from the surface runoff and subsurface runoff, respectively, which were estimated by the DLEM land model. More details about the terrestrial carbon processes can be found in the supplementary information and in the work of Tian et al., (2012). $Q_{\text {sub }}$ is the flow rates of subnetworks $\left(\mathrm{m}^{3} \cdot \mathrm{s}^{-1}\right)$, $C_{\text {sub }}$ is the concentration $\left(\mathrm{gC} \cdot \mathrm{m}^{-3}\right)$ of all three carbon species in the hillslope flow, groundwater, and subnetworks, respectively.

The advective carbon fluxes through the main-channel are described as

$$
F_{a, \text { main }}=\sum_{i=1}^{n} Q_{\mathrm{up}, i} C_{\mathrm{up}, i}+Q_{\mathrm{sub}} C_{\mathrm{sub}}-Q_{\mathrm{main}} C_{\text {main }}
$$

where $Q_{\text {up }}$ and $Q_{\text {main }}$ are the outflow rates of upstream grid cells and the main channel in the current grid cell $\left(\mathrm{m}^{3} \cdot \mathrm{s}^{-1}\right)$, respectively. $C_{\text {up }}$ and $C_{\text {main }}$ are the associated concentrations $\left(\mathrm{gC} \cdot \mathrm{m}^{-3}\right)$ of carbon species, respectively.

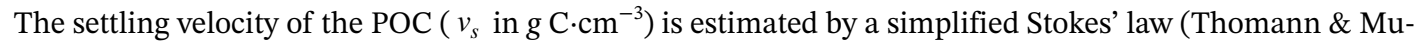
eller, 1987), and is given by:

$$
v_{s}=0.033634 \alpha\left(\rho_{s}-\rho_{w}\right) d^{2}
$$

where $\rho_{s}$ and $\rho_{w}$ are the density of particle and water $\left(\mathrm{g} \cdot \mathrm{cm}^{-3}\right)$, respectively. D is the diameter of the particle $(\mu \mathrm{m})$, set to $5 \mu \mathrm{m}$ for POC, an intermediate value in the $1-10 \mu \mathrm{m}$ range suggested by Chapra (2008). The size of the particle does not change through the river network. $\alpha$ (dimensionless) reflects the effect of the particle shape on the settling velocity (for a sphere it is 1.0). Sediment resuspension is not included in the model. The first-order respiration rate coefficient is given by 


$$
R_{D O C, P O C}=K_{D O C, P O C}\left(Q_{10}\right)^{\frac{T_{w}-T_{s}}{10}}
$$

where $K_{D O C, P O C}$ is the base of decomposition rate of DOC and POC $\left(\mathrm{d}^{-1}\right), T_{w}$ is the water temperature $\left({ }^{0} \mathrm{C}\right)$, which is calculated based on an empirical relationship with air temperature (Mohseni et al., 1998, 1999), $T_{s}$ is the reference temperature $\left(20^{\circ} \mathrm{C}\right)$, and $Q_{10}$ (set as 2$)$ is the change fraction of $\mathrm{C}$ reaction rates at a temperature change of $10^{\circ} \mathrm{C}$.

The DLEM explicitly quantifies the $\mathrm{CO}_{2}$ exchange between water bodies and the atmosphere. The major controlling factors are temperature, water $\mathrm{pH}$, flow velocity, and air $\mathrm{CO}_{2}$ concentration. Here, the net $\mathrm{CO}_{2}$ degassing $E_{\mathrm{CO} 2}$ is estimated as

$$
E_{\mathrm{CO} 2}=K_{\mathrm{CO} 2} \cdot\left(C_{\mathrm{CO} 2}-C_{\mathrm{CO} 2 \mathrm{eq}}\right) \cdot A_{s}
$$

where $K_{\mathrm{CO} 2}$ is the gas transfer velocity $\left(\mathrm{m} \cdot \mathrm{d}^{-1}\right), C_{\mathrm{CO} 2}$ is the dissolved $\mathrm{CO}_{2}$ concentration in the water, and $C_{\mathrm{CO} 2 \mathrm{eq}}$ is the equilibrium $\mathrm{CO}_{2}$ concentration $\left(\mathrm{gC} \cdot \mathrm{m}^{-3}\right) . C_{\mathrm{CO} 2}$ is estimated as a fraction of the DIC concentration $\left(C_{D I C} ; \mathrm{gC} \cdot \mathrm{m}^{-3}\right)$ which is controlled by water $\mathrm{pH}$ and water temperature (Chapra, 2008). The $\mathrm{pH}$ values were obtained from the GLORICH database (Hartmann et al., 2019), which has been interpolated to the DLEM grid (Figure S1). $C_{\mathrm{CO} 2 \mathrm{eq}}\left(\mathrm{g} \mathrm{C} \cdot \mathrm{m}^{-3}\right)$ is calculated based on Henry's law (Sander, 2015):

$$
C_{\mathrm{CO} 2 \mathrm{eq}}=P_{\mathrm{CO}_{2}} \cdot 0.034 \cdot \operatorname{EXP}\left(2400 \cdot\left(\frac{1}{273+T_{w}}-\frac{1}{298}\right)\right)
$$

where $T_{w}\left({ }^{\circ} \mathrm{C}\right)$ is the water temperature. $K_{\mathrm{CO} 2}$ is estimated as

$$
K_{\mathrm{CO} 2}=K_{600} \cdot\left(\frac{S c_{\mathrm{CO} 2}}{600}\right)^{-0.5}
$$

where $S c_{\mathrm{CO} 2}$ is the Schmidt number for $\mathrm{CO}_{2}$ (He et al., 2017) and $K_{600}$ is the gas velocity at a Schmidt number of 600 (Raymond et al., 2012). $S c_{\mathrm{CO} 2}$ is calculated from

$$
S c_{\mathrm{CO} 2}=1,911.1-118.11 \cdot T_{w}+3.4527 \cdot T_{w}{ }^{2}-0.04132 \cdot T_{w}{ }^{3}
$$

$K_{600}\left(\mathrm{~m} \mathrm{~d}^{-1}\right)$ is calculated from

$$
K_{600}=S \cdot V \cdot 2,841.6+2.03
$$

where $S$ is the channel slope, and $V$ is the flow velocity $\left(\mathrm{m} \cdot \mathrm{s}^{-1}\right)$ derived from Manning's equation.

\section{Simulation Protocol and Input Data}

\subsection{Simulation Experiments}

The DLEM simulation follows three major steps. In the first step, we conducted an equilibrium run driven by the potential natural vegetation map, $\mathrm{CO}_{2}$ concentration, land use, nitrogen management, and other forcings fixed at values representative of 1,900, and 30-year average daily climate forcing from 1900 to 1930. This run was stopped when all carbon, nitrogen, and water pools reached an equilibrium state. In the second step, we smoothed the results between this equilibrium run and each ensuing transient run (Table 1) by conducting a 30-year spin-up run (Thornton \& Rosenbloom, 2005; Tian et al., 2012) which randomly selected the driving forces between 1900 and 1929. In the third and final step, the model was run from 1900 to 2015 with all the forcings changing year-by-year.

To attribute the contribution of climate variability, land use change, nitrogen deposition, nitrogen management, and atmospheric $\mathrm{CO}_{2}$ concentration to the riverine carbon fluxes, we designed a set of simulation 
Table 1

Simulation Experimental Design for Attributing Riverine Carbon Fluxes to Natural and Anthropogenic Factors, Including Climate, Atmospheric Carbon Dioxide $\left(\mathrm{CO}_{2}\right)$, Nitrogen Deposition (NDEP), and Nitrogen Management $(N M A N)$

\begin{tabular}{lccccc}
\hline & \multicolumn{5}{c}{ Factors } \\
\hline & Climate & $\mathrm{CO}_{2}$ & Land-use & NDEP & NMAN \\
\hline Simulation 1 & $1900-2015$ & $1900-2015$ & $1900-2015$ & $1900-2015$ & $1900-2015$ \\
Simulation 2 & $1900-2015$ & $1900-2015$ & $1900-2015$ & $1900-2015$ & 1900 \\
Simulation 3 & $1900-2015$ & $1900-2015$ & $1900-2015$ & 1900 & $1900-2015$ \\
Simulation 4 & $1900-2015$ & $1900-2015$ & $1900-2015$ & $1900-2015$ \\
Simulation 5 & $1900-2015$ & 1900 & $1900-2015$ & $1900-2015$ & $1900-2015$ \\
Simulation 6 & 1900 & $1900-2015$ & $1900-2015$ & $1900-2015$ & $1900-2015$ \\
\hline
\end{tabular}

experiments which are consistent with our previous model intercomparison studies (Tian et al., 2018; Tian, Yang, et al., 2015; Xu et al., 2010; Table 1). We first ran the all-combined simulation as a reference simulation (Simulation 1). Then we conducted a series of five factorial experiments (Simulations 2-6; Table 1) by keeping each of the five driving factors constant at their 1,900 levels: in Simulation 2 nitrogen fertilizer and manure usage were held constant, in Simulation $3 \mathrm{NO}_{\mathrm{y}}$ and $\mathrm{NH}_{\mathrm{x}}$ deposition were held constant, in Simulation 4 land use was held constant, in Simulation 5 atmospheric $\mathrm{CO}_{2}$ concentration was held constant, and in Simulation 6 climate was held constant throughout the simulation. The contribution of each factor to the carbon fluxes was quantified by comparing carbon fluxes of Simulations 2-6 with the reference simulation (Simulation 1).

\subsection{Input Data}

Data sets for climate, land use cohort, nitrogen inputs, and atmospheric $\mathrm{CO}_{2}$ concentration were developed at a $4 \mathrm{~km}$ resolution as inputs to the DLEM.

To reconstruct historical land use/land cover for the study area, we combined data from multiple sources (Figure S2), including the National Land Cover Database (Homer et al., 2015), North American Land Cover (http://landcover.usgs.gov/nalcms.php), Global C4 vegetation map (Still et al., 2003), county-level land use inventories (Waisanen \& Bliss, 2002), and the Global Lakes and Wetlands Database (http://www. worldwildlife.org/pages/global-lakes-and-wetlands-database). Due to the massive urbanization trend over the last century, cropland area decreased by 53\%, while urban area increased by 497\% from 1900 to 2015. Constrained by cropland conversion and urban expansion, forest coverage, which is the dominant natural vegetation in the study area, increased by $10 \%$ (Figures 3a, 3c, and 3d) and grassland increased by $21 \%$.

The daily climate data set was obtained from PRISM (Daly et al., 2008). This data set provides gridded estimates of four essential climate variables including daily minimum, mean, and maximum temperature, and precipitation. Over the study area, precipitation and temperature demonstrated significant spatial and temporal variability during 1900-2015 (Figures 3b, 3e, and 3f). The average annual precipitation ( \pm 1 standard deviation) was $1,080.0 \pm 131.7 \mathrm{~mm} \cdot \mathrm{yr}^{-1}$ with the maximum and minimum precipitation occurring in $2003(1,506 \mathrm{~mm})$ and $1930(658 \mathrm{~mm})$, respectively. Temperature demonstrated significant interannual variability. The annual mean temperature in this area was $11.6 \pm 0.2^{\circ} \mathrm{C}$ during $1900-2015$. We conducted the Mann-Kendal trend test and the Theil-Sen linear regression to examine the increasing trend of air temperature and precipitation (Figures $3 e$ and 3f). The annual total precipitation and annual mean temperature showed considerable fluctuations, with significant increasing trends from 1900 to 2015. The warming trend, and specifically the increasing trend since 1960, is consistent with the observed increase in greenhouse gases whereas the precipitation trend more likely reflects natural variability (Kunkel et al., 2013). In particular, this region was characterized by drought conditions in the 1960s and much wetter ("pluvial") conditions in the following decades, and such variability may have been internal to the atmosphere (Seager et al., 2012) or resulting from atmosphere-ocean interactions (Schulte et al., 2017). 

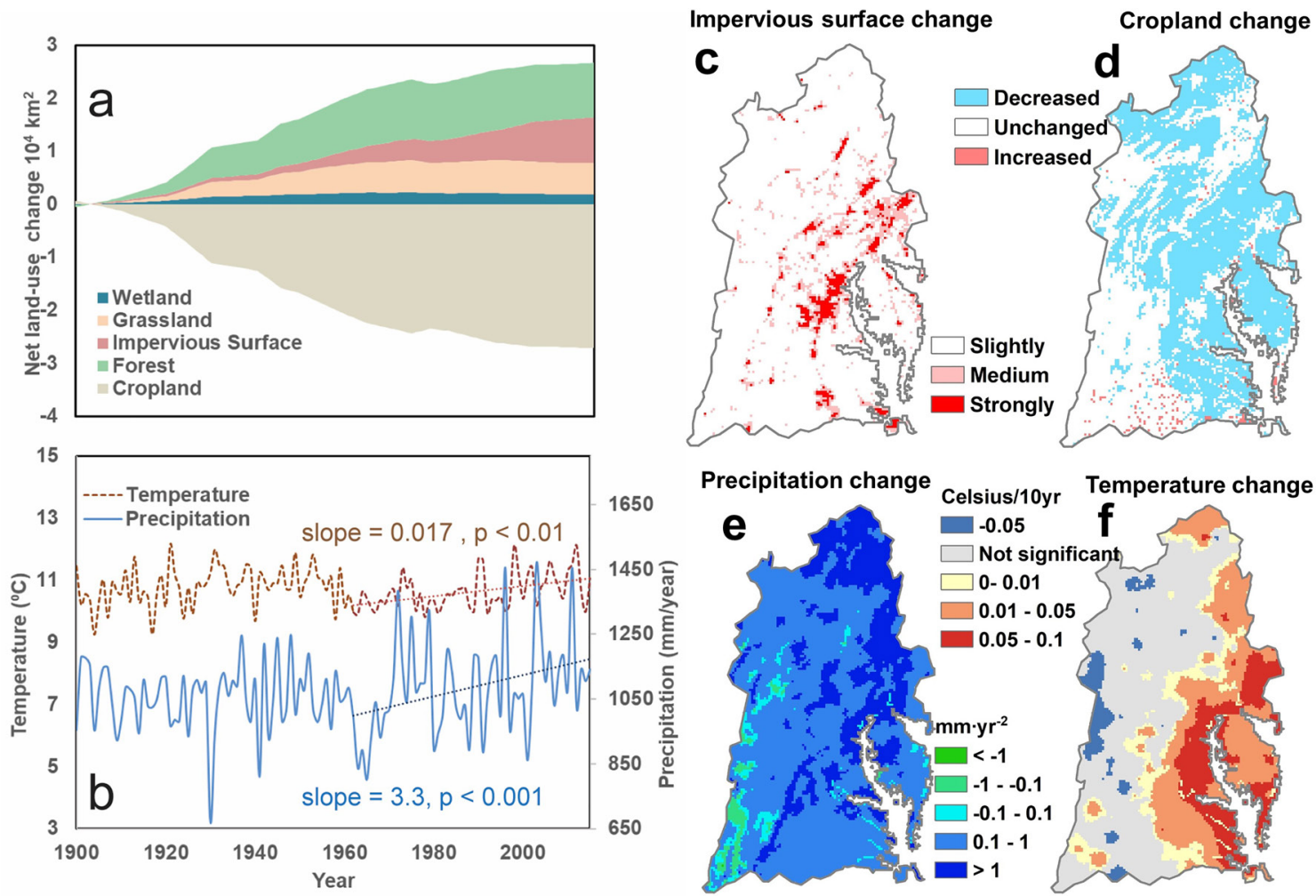

Figure 3. Land cover change and climate variability in the Chesapeake and Delaware Bay Watersheds during 1900-2015. (a) Temporal patterns of net land-use change. (b) Temporal patterns of annual mean precipitation and air temperature. (c) Changes in urban impervious surface (Note: slightly means $10 \%$, medium means 30\%, and strongly means 50\%). (d) Changes in cropland. (e) The change rate of annual precipitation. (f) The change rate of annual mean air temperature.

The scale-adaptive water transport module requires several types of hydrograph data as inputs. Flow direction, bank-full width, and bank-full depth are obtained from the HYDRO1K database (Earth Resources Observation And Science Center, 2017) which was derived from hydrological corrected topographic data (Tarboton, 1997). We also calculated stream orders based on the HYDRO1K for data analysis (Figure 1). The total length of river channels within a 4-km grid cell, derived from the National Hydrography Dataset plus v2 data, was used to quantify the length of hillslope flow and subnetwork flow (NHDPlus, available at: http://www.horizon-systems.com/NHDPlus/index.php) (Li et al., 2013). The Manning's roughness coefficient of each grid cell was calculated from the land cover and the water depth. More details regarding how to calculate bank-full depth, band-full width, and the Manning's roughness coefficient can be found in the work of Getirana et al., (2012). The slope of the main river channel was derived from the HydroSHEDS and HYDRO1K data sets, and we averaged the mean channel slope of the headwater streams within a 4-km grid cell based on the NHDPlus database. The major dam information used in this study was derived from the Global Reservoir and Dam database (Lehner et al., 2011), and it was nested into the 4-km grid level and used to quantify the damming effect on POC deposition (Vörösmarty et al., 2003).

\subsection{Model Evaluation}

Model performance was assessed by comparing the carbon fluxes of the major rivers in the study region predicted by the DLEM (with the MOSART water transport component incorporated) during 1979-2015 with the statistical estimates of the LOADEST (Runkel et al., 2004) derived directly from the USGS water quality observations. A total of nine USGS sites were selected based on data availability. Detailed information about the USGS sites used for model evaluation can be found in Table S1. We calculated the Nash-Sutcliffe model efficiency coefficient (NSE; Nash \& Sutcliffe, 1970) and the coefficient of determination $\left(R^{2}\right)$ to evaluate the model performance in predicting the DOC, DIC, and POC fluxes at each site (Figure 4). Most of the 

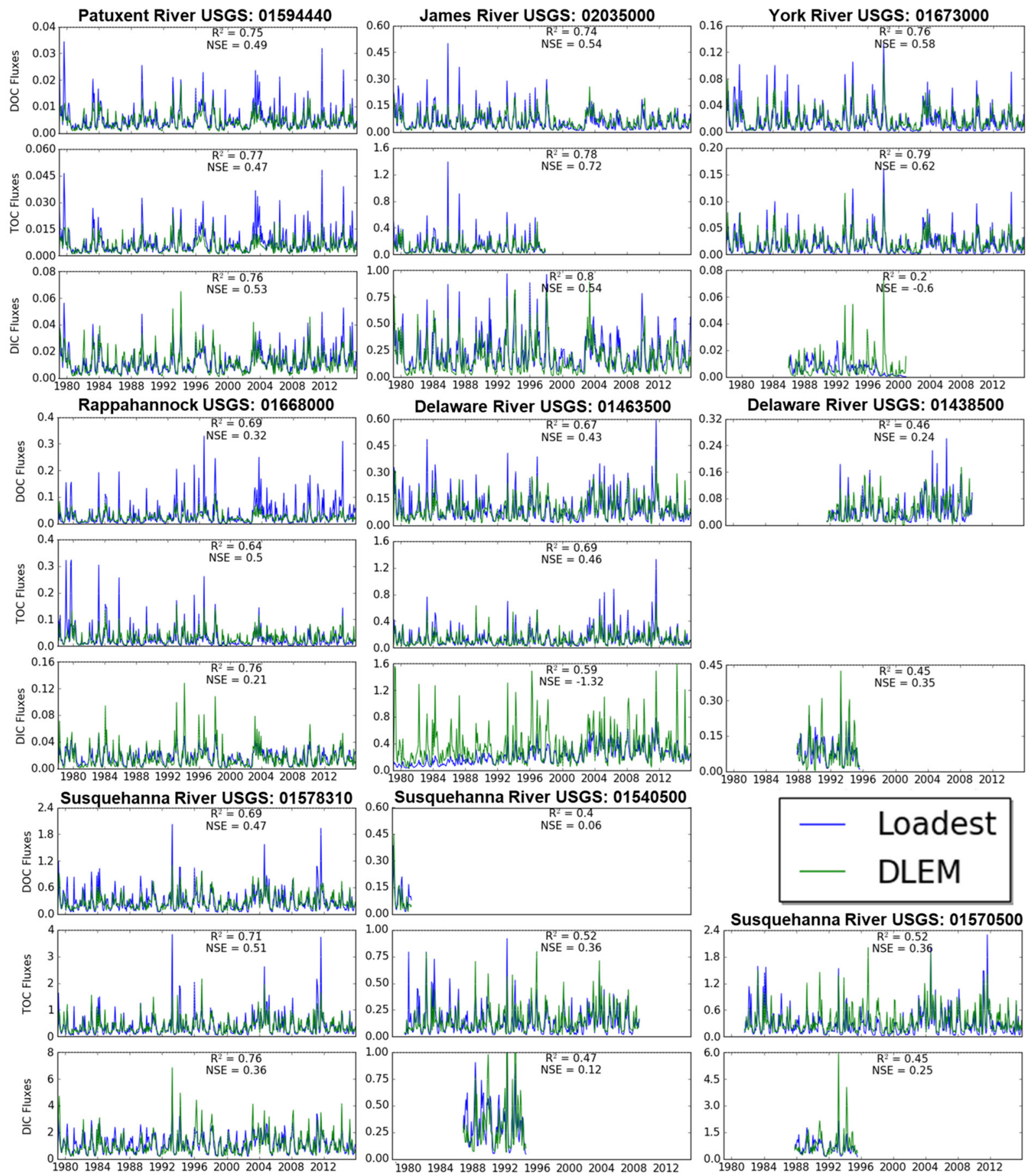

Figure 4. A comparison of DLEM-simulated carbon fluxes with LOADEST estimations derived from USGS observations. Note that the vertical scales are different for subplots. See Figure 1 for site locations. DLEM, Dynamic Land Ecosystem Model; LOADEST, Load Estimator. 

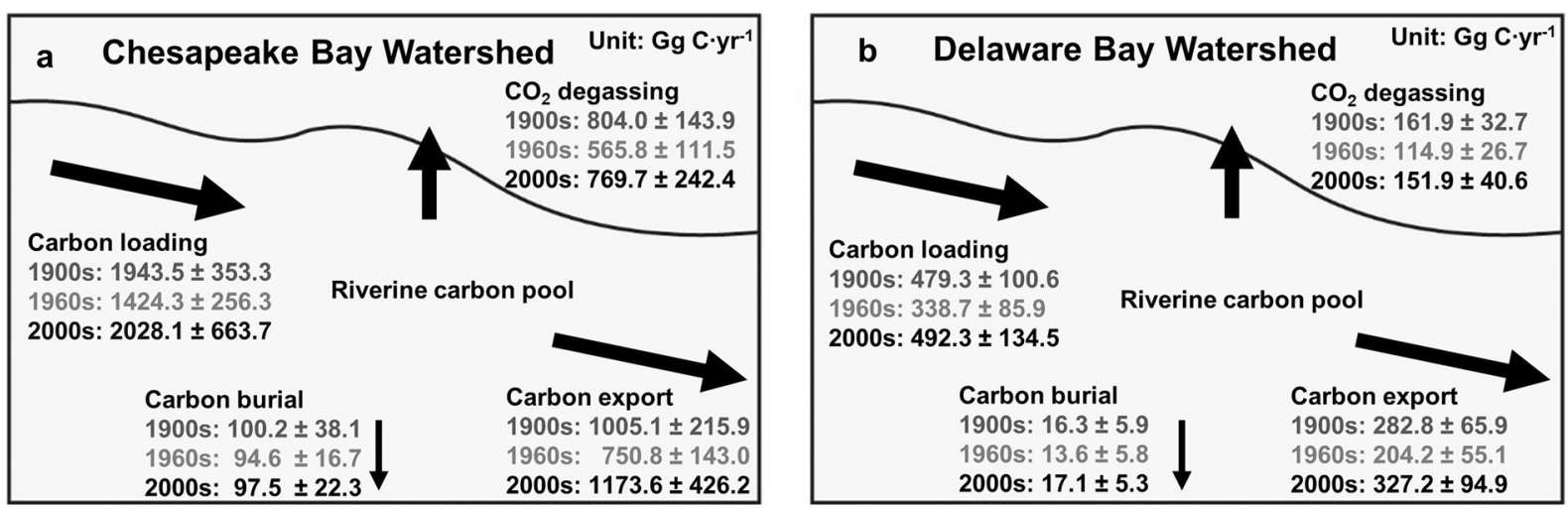

Figure 5. Carbon fluxes in (a) the Chesapeake Bay Watershed and (b) Delaware Bay Watershed river networks simulated by DLEM. Shown are means \pm 1 standard deviation of the annual means for three different decades (1900s, 1960s, and 2000s). Note that total carbon export represents the sum of DIC, DOC and POC exports. DIC, dissolved inorganic carbon; DLEM, Dynamic Land Ecosystem Model; DOC, dissolved organic carbon; POC, particulate organic carbon.

riverine carbon export predicted by the DLEM agreed well with the LOADEST estimates; of the 18 time series 30 years or longer, 11 have $R^{2}>0.7$ and 12 have NSE $>0.4$.

\section{Results}

\subsection{Budget and Temporal Patterns of Riverine Carbon Fluxes}

In the CBW, total riverine carbon export $\left(1,173.6 \pm 426.2 \mathrm{Gg} \mathrm{C} \cdot \mathrm{yr}^{-1}\right)$ constituted $57 \%$ of the total terrestrial carbon loading $\left(2,028.1 \pm 663.7 \mathrm{Gg} \mathrm{C} \cdot \mathrm{yr}^{-1}\right)$, on average, during the 2000s. To this export, DOC, DIC, and POC contributed $14 \%, 39 \%$, and $4 \%$, respectively (Figures $5 \mathrm{a}$ and $6 \mathrm{e}$ ). During the lateral transport from land to ocean, about $38 \%$ was released to the atmosphere in the form of $\mathrm{CO}_{2}(\mathrm{~g})$, and only $5 \%$ was buried in sediments (Figures 5a and 6b). In the DBW, riverine carbon export $\left(327.2 \pm 94.9 \mathrm{Gg} \mathrm{C} \cdot \mathrm{yr}^{-1}\right)$ constituted $66 \%$ of the total terrestrial carbon loading $\left(492.3 \pm 134.5 \mathrm{Gg} \mathrm{C} \cdot \mathrm{yr}^{-1}\right)$ averaged over the 2000s. DOC, DIC, and POC contributed, on average, $13 \%, 49 \%$, and 5\%, respectively, to the terrestrial carbon loading (Figures 5b and 6f). The $\mathrm{CO}_{2}$ degassing and burial, as the major carbon removal processes, account for $31 \%$ and $3 \%$ of the total riverine carbon fluxes (Figures $5 \mathrm{~b}$ and $6 \mathrm{~b}$ ). Although the averaged carbon fluxes of the 1900s and 2000s (decade) are comparable, we observed a nearly twofold increase in the standard deviation of carbon loading, degassing, and exports in the 2000s, implying a remarkable response of riverine carbon dynamics to extreme climate events (Figure 5). Collectively, the magnitude of inorganic carbon exports and riverine $\mathrm{CO}_{2}$ degassing was comparable, which constituted the majority of the riverine carbon fluxes over the two regions, on average, during 1900-2015 (Figures 5 and 6).

Simulated results show consistent temporal patterns of flow discharge and riverine $\mathrm{C}$ fluxes in the two river basins (Figures 6a, 6e, and 6f). Specifically, a devastating drier period (the 1960s) was observed for both watersheds, resulting in a significant decrease in terrestrial carbon loading and riverine carbon fluxes (Figures 5 and 6a). However, the concentrations of carbon species (total carbon export divided by total flow discharge) help explain the long-term changes in the riverine carbon balance (Figures $6 \mathrm{c}$ and $6 \mathrm{~d}$ ). The DIC concentration increased significantly in the CBW from 1960 to 2015 . However, we do not observe significant changes in the DIC concentration in the DBW during the last century. The DOC concentration in both basins shows significantly increasing trends $(p<0.05)$ from 1900 to 2015 , while the POC concentration does not show a statistically significant trend $(p>0.05)$.

\subsection{Spatial and Temporal Patterns of Terrestrial Carbon Loading and Riverine $\mathrm{CO}_{2}$ Degassing}

We conducted the Mann-Kendal trend test and the Theil-Sen linear regression to each grid cell within the CBW and the DBW over the full study period from 1900 to 2015 (Figure 7). In the eastern and northern parts of the CBW, DOC loading increased significantly (Figure 7a), with a rate of $0.002-0.004 \mathrm{~g} \mathrm{C} \mathrm{m}^{2} \cdot \mathrm{yr}^{-2}$. Across the southern part of the CBW and most of the DBW, the average rate of DOC loading increase 

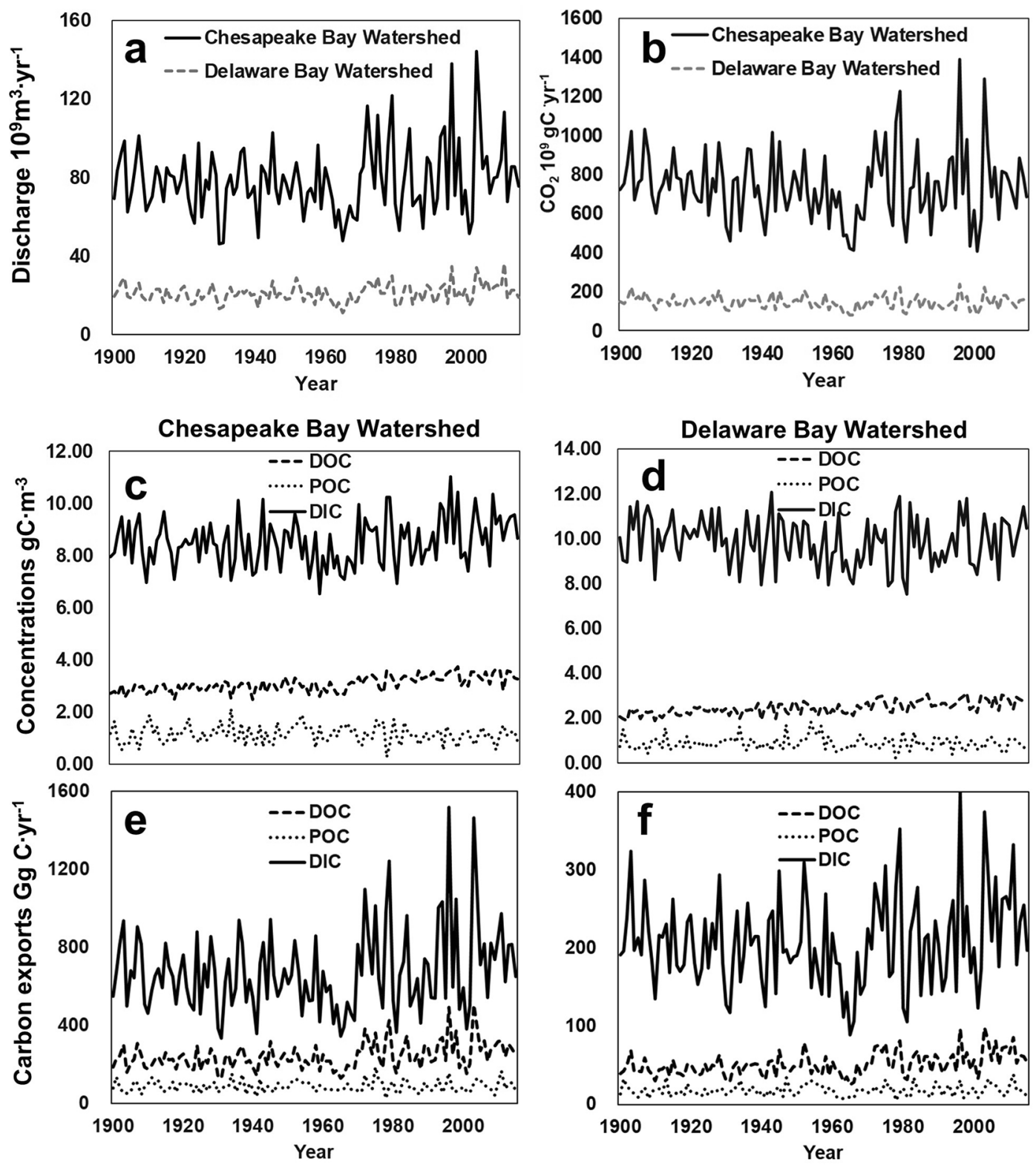

Figure 6. DLEM-simulated discharge (a), $\mathrm{CO}_{2}$ degassing (b), carbon concentrations (c), (d) and riverine carbon fluxes (e), (f) in the Chesapeake Bay Watershed and Delaware Bay Watershed from 1900 to 2016. Note that the vertical scales are different for subplots. DLEM, Dynamic Land Ecosystem Model.

was even greater $\left(0.004-0.008 \mathrm{~g} \mathrm{C} \mathrm{m}^{-2} \mathrm{yr}^{-2}\right)$. Terrestrial POC loading did not exhibit a significant increasing or decreasing trend in much of the inland region of the study area. The changes in POC loading in the coastal zones showed considerable spatial variability, with either significant decreases or increases of $0.003 \mathrm{~g} \mathrm{C} \mathrm{m}^{-2} \mathrm{yr}^{-2}$ (Figure 7b).

The northern part of the DBW region showed a large increasing trend in DIC loading with an increasing rate of $0.02-0.05 \mathrm{gC} \mathrm{m}^{-2} \mathrm{yr}^{-2}$. In the southern part of the study region, there is a slightly smaller significant increasing trend of DIC loading of $0.01-0.02 \mathrm{gC} \mathrm{m}^{-2} \mathrm{yr}^{-2}$. Most of the remaining areas in the study region have no significant increasing or decreasing trend (Figure 7c).

The total riverine $\mathrm{CO}_{2}$ degassing of the CBW and the DBW predicted by the DLEM is about $886.25 \pm 207.49 \mathrm{Gg}$ $\mathrm{C} \cdot \mathrm{yr}^{-1}$, which accounts for $39 \%$ of the terrestrial carbon loading in the 2000s. The headwater streams (first order-third stream order include the subnetworks and the stream orders derived from the HYDRO1k data 


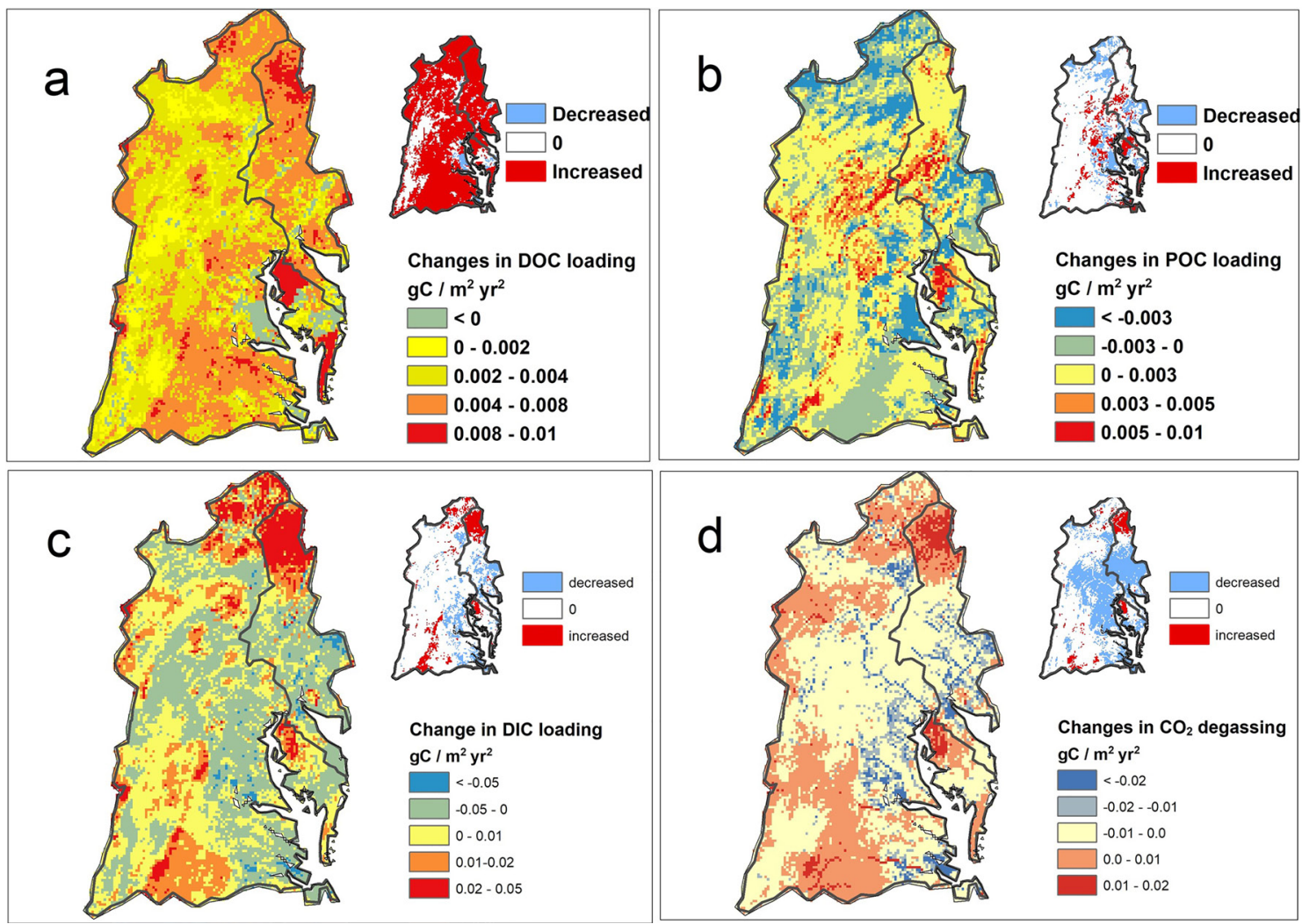

Figure 7. Spatiotemporal patterns of changes in terrestrial carbon loading of (a) DOC, (b) POC, and (c) DIC and riverine $\mathrm{CO}_{2}$ degassing (d) from 1900 to 2015. DIC, dissolved inorganic carbon; DOC, dissolved organic carbon; POC, particulate organic carbon.

set) cover $79 \%$ of the total water surface area (Allen \& Pavelsky, 2018). They account for a large fraction (73\%) of the total riverine $\mathrm{CO}_{2}$ effluxes in this study (Figure 8c). The $\mathrm{CO}_{2}$ degassing directly correlates with the riverine DIC concentration and the terrestrial DIC loading. The northern part of the DBW shows large increasing trends of $0.1-0.2 \mathrm{gC} \mathrm{m}^{-2} \mathrm{yr}^{-2}$. However, riverine $\mathrm{CO}_{2}$ degassing throughout most of the study region shows a significant decreasing trend with a slight rate of about $-0.01 \mathrm{gC} \mathrm{m}^{-2} \mathrm{yr}^{-2}$ primarily due to the decrease of DIC leaching from the land (Figures $7 \mathrm{c}$ and $7 \mathrm{~d}$ ).

\subsection{Factorial Contributions to the Riverine Carbon Fluxes in the CBW and DBW}

The factorial experiments revealed the contribution of each of the five factors studied (Table 1) to decadal averages in flow discharge and riverine carbon exports in the CBW and DBW from 1900 to 2015 (Figure 9). Climate variability, that is, variability of temperature and precipitation, explain most of the variations in the total flow discharge of both watersheds, with land use conversions playing an additional, but minor, role. Other factors, including changes in $\mathrm{N}$ deposition, $\mathrm{N}$ management, and atmospheric $\mathrm{CO}_{2}$, do not substantially impact the changes in river flow discharge (Figures 9a and 9b). For the three riverine carbon species, climate variability again plays the most important role in explaining decade to decade variations in carbon export. On the other hand, the other four factors contribute to the long-term (century-scale) changes in carbon fluxes.

In both the CBW and the DBW, land use conversion plays a large role in explaining the long-term changes in POC and DIC fluxes, $\mathrm{N}$ management and $\mathrm{N}$ deposition play a substantial role in altering organic carbon fluxes (DOC and POC), and atmospheric $\mathrm{CO}_{2}$ impacts DIC fluxes, particularly in the larger CBW (Figures 9c-9g).

Before the 1960s, climate variability explains most of the variations in DOC for both the CBW and the DBW. After the 1960s, the impact of other factors on DOC fluxes increased substantially. In the CBW, climate 


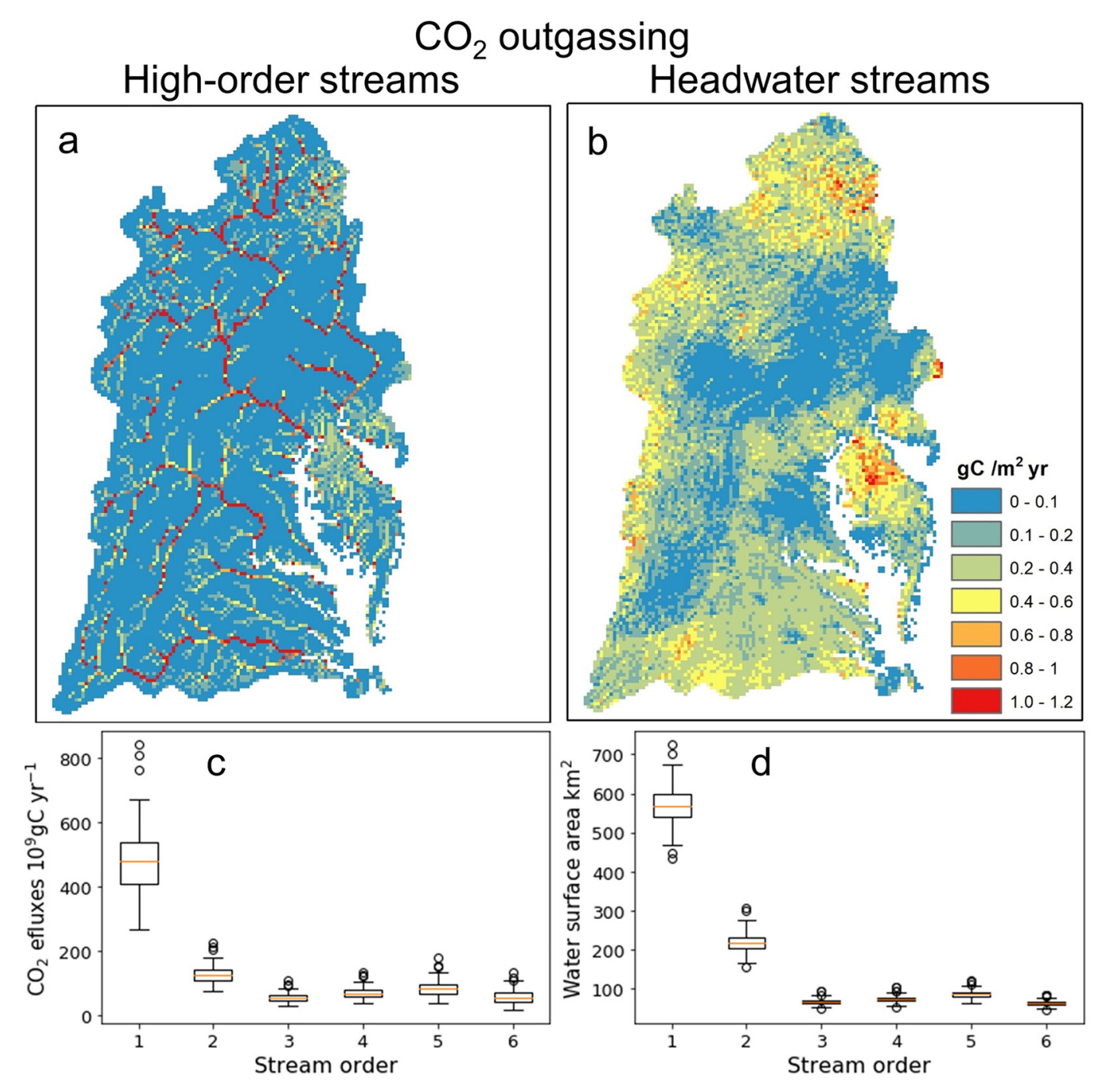

Figure 8. Simulated $\mathrm{CO}_{2}$ emissions from high-order streams (a) and headwater streams (b) in 2015. Averaged annual total $\mathrm{CO}_{2}$ emission for stream orders 1-6 (c) across the Chesapeake Bay Watershed and (d) across the Delaware Bay Watershed from 1900 to 2015.

change increased DOC export by $34.3 \mathrm{Gg} \mathrm{C} \cdot \mathrm{yr}^{-1}$ in the 2000 s with respect to the level of 1,900 , followed by $\mathrm{N}$ deposition (23.5 Gg C.yr $\left.{ }^{-1}\right)$, $\mathrm{N}$ management $\left(10.3 \mathrm{Gg} \mathrm{C} \cdot \mathrm{yr}^{-1}\right)$, and $\mathrm{CO}_{2}\left(4.4 \mathrm{Gg} \mathrm{C}_{\mathrm{yr}} \mathrm{yr}^{-1}\right)$, while land use change decreased DOC export by $20.6 \mathrm{Gg} \mathrm{C} \cdot \mathrm{yr}^{-1}$ (Figure 9c). Furthermore, in the DBW, climate variability increased DOC export by $18.2 \mathrm{Gg} \mathrm{C} \cdot \mathrm{yr}^{-1}$, followed by $\mathrm{N}$ deposition $\left(6.6 \mathrm{Gg} \mathrm{C} \cdot \mathrm{yr}^{-1}\right) \mathrm{N}$ management $\left(2.9 \mathrm{Gg} \mathrm{C} \mathrm{yr}^{-1}\right)$ and

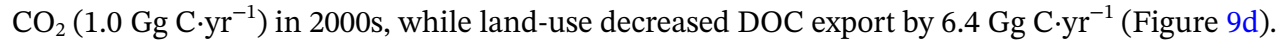

Unlike the long-term change in DOC export, which was strongly regulated by multiple factors, the determinative factors for the changes in POC export are limited to climate variability and land conversion. Here, climate variability explained most of the variations in POC export in both the CBW and the DBW from the 1900 s to the 2000s (Figures 9e and 9f). The contribution of land conversion increased to $-7.8 \mathrm{Gg} \mathrm{C}^{\mathrm{yr}} \mathrm{yr}^{-1}$ in the DBW in the $2000 \mathrm{~s}$, comparable, though opposite in sign, to that of the climate $\left(8.0 \mathrm{Gg} \mathrm{C} \cdot \mathrm{yr}^{-1}\right)$. Moreover, in the CBW during the 2000s, the impact of land conversion on POC export reached $-21.6 \mathrm{Gg} \mathrm{C} \cdot \mathrm{yr}^{-1}$, exceeding the climate impact (15.2 Gg C.yr ${ }^{-1}$; Figure 9e) in magnitude.

DIC export was strongly affected by climate variability as well; however, the impacts of land use change and atmospheric $\mathrm{CO}_{2}$ concentration have been significant. In the CBW from the 1900 s to the 2000s, climate variability increased DIC export by $83.2 \mathrm{Gg} \mathrm{C} \cdot \mathrm{yr}^{-1}$, followed by the $\mathrm{CO}_{2}$ effect $\left(59.6 \mathrm{Gg} \mathrm{C} \cdot \mathrm{yr}^{-1}\right)$, and land use 

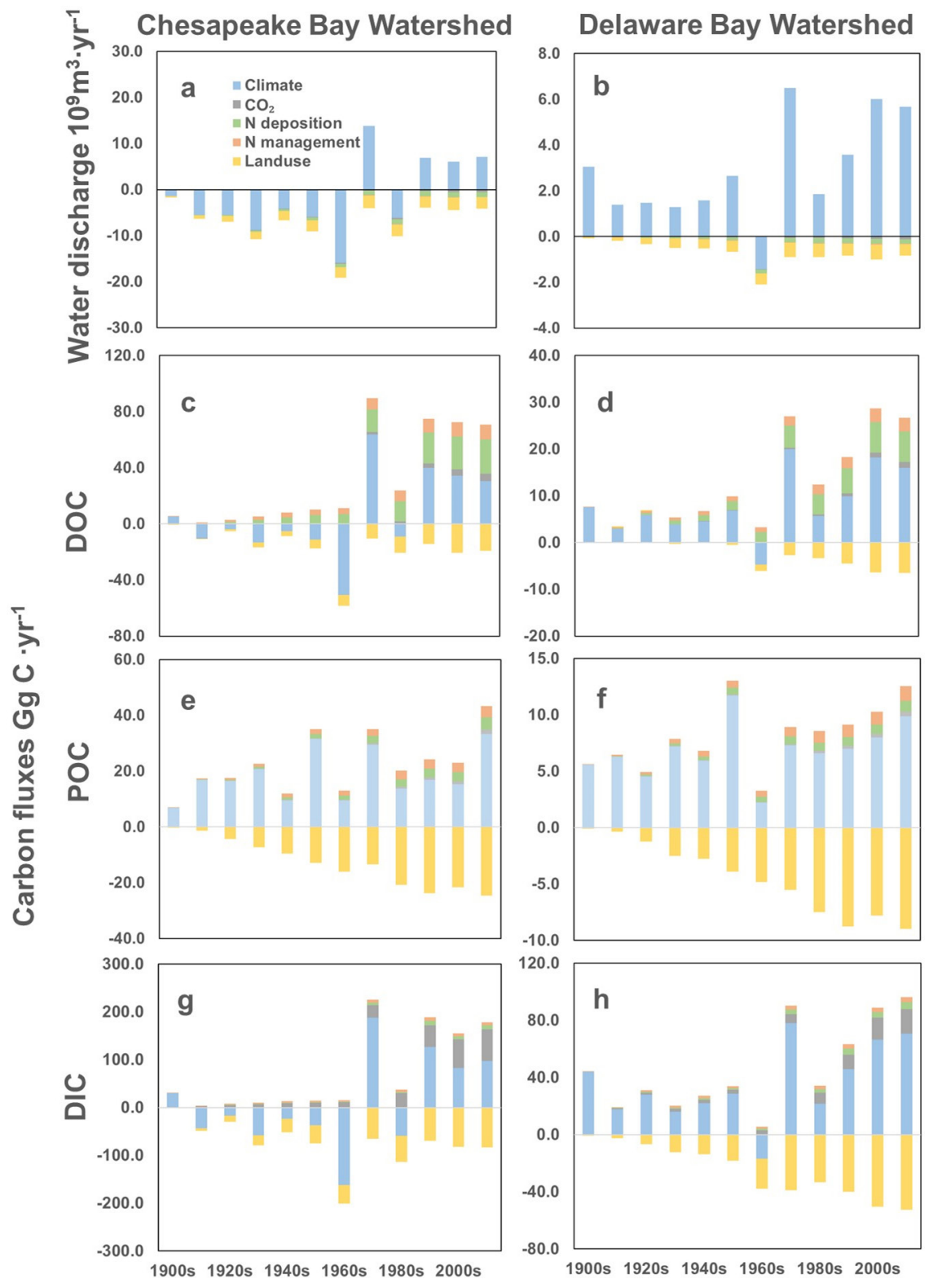

Figure 9. Decadal mean contribution of climate, $\mathrm{CO}_{2}, \mathrm{~N}$ deposition, $\mathrm{N}$ management $(\mathrm{N}$ fertilizer $+\mathrm{N}$ manure), and land-use change to water discharge in the CBW (a) and DBW (b), DOC export in the CBW (c) and DBW (d), POC export in the CBW (e) and DBW (f), and DIC export in the CBW (g) and DBW (h). Shown are the fluxes from the reference (all-combined) simulation minus the simulation with the particular forcing held at its 1,900 value (see Section 3.1 and Table 1). Note differences in vertical axes. All averages are complete decades except for the 2010s, which only include 2010-2015. CBW, Chesapeake Bay Watershed; DBW, Delaware Bay Watershed; DIC, dissolved inorganic carbon; DOC, dissolved organic carbon; POC, particulate organic carbon.

change decreased DIC export by $-81.9 \mathrm{Gg} \mathrm{C} \cdot \mathrm{yr}^{-1}$ (Figure 9g). Similar results were found for the DBW over the same time period; climate variability increased DIC export by $66.6 \mathrm{Gg} \mathrm{C} \cdot \mathrm{yr}^{-1}$, followed by the $\mathrm{CO}_{2}$ effect

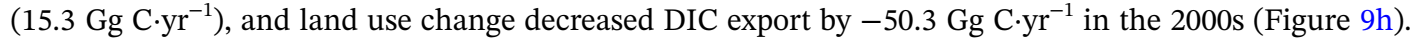
Nitrogen inputs had a slight impact on DIC exports in both regions (Figures $9 \mathrm{~g}$ and $9 \mathrm{~h}$ ). 


\section{Discussion}

\subsection{Riverine $\mathrm{CO}_{2}$ Degassing in the $\mathrm{CBW}$ and $\mathrm{DBW}$}

One of the major contributions of this study is that we demonstrated a more realistic model representation of riverine $\mathrm{CO}_{2}$ degassing. Specifically, we utilized a new statistical method (Allen et al., 2018) to better estimate the surface area of the headwater streams within the subgrid river routing scheme (Li et al., 2013). The improved parameterization can be used to simulate $\mathrm{CO}_{2}$ degassing from small streams, which has been ignored in many previous studies (Laruelle et al., 2015, 2017; Marescaux et al., 2020; Tian, Ren, et al., 2015; Tian, Yang, et al., 2015). The resulting statistics of the total $\mathrm{CO}_{2}$ degassing as a function of stream order predicted by the DLEM (Figure 8c) follows a similar pattern for the inventory-based data analysis across the conterminous U.S. (Butman \& Raymond, 2011). Additionally, the first to third order streams, which are characterized as headwater streams in this analysis, account for $73 \%$ of the total riverine $\mathrm{CO}_{2}$ degassing. This finding is consistent with previous experimental analysis (Argerich et al., 2016) and global inventory-based analysis (Raymond et al., 2013), which suggest that headwater streams account for $70 \%$ of riverine $\mathrm{CO}_{2}$ degassing.

The importance of small streams to regional biogeochemical cycles and greenhouse gas emissions has been documented in previous studies (e.g., Beckman \& Wohl, 2014). The higher $\mathrm{CO}_{2}$ degassing from headwater streams is mainly due to larger water surface area (Figure 8d); our statistics do not directly imply a higher flux rate of $\mathrm{CO}_{2}$ degassing in the first and second order streams. The headwater streams are temporary waterways. Thus, the first and second order streams are dry most days of the year, which lowers the overall annual $\mathrm{CO}_{2}$ emission. Other factors can also help explain the higher $\mathrm{CO}_{2}$ emissions from headwater steams, such as higher DIC or DOC concentrations, even though the DOC decomposition rate in the headwater zone is typically much lower than that of large river channels (Varol \& Li, 2017). Moreover, the gas transfer velocity of headwater streams is higher than that of large river channels due to the higher channel slope of the headwater streams. The $\mathrm{CO}_{2}$ degassing from headwater small streams is also very sensitive to climate variability, with the largest outlier values in the statistics of $\mathrm{CO}_{2}$ degassing (Figure 8c) occurring in first order streams (Figure 8c). Modeling studies that oversimplify headwater stream processes may substantially underestimate the magnitude and variability of $\mathrm{CO}_{2}$ degassing.

The low emission rates in the central regions of the study area are mainly due to the dominance of cropland (Figure 3), where extensive liming substantially increases the water $\mathrm{pH}$ of both ground water and surface water (Asabere et al., 2018; Naylor \& Schmidt, 1986; Figure S2). Water pH is critical for emission rates as it plays an essential role in regulating the partitioning among the three DIC species $\left(\mathrm{H}_{2} \mathrm{CO}_{3}, \mathrm{HCO}_{3}{ }^{-}\right.$, and $\mathrm{CO}_{3}{ }^{2-}$ ), as described in the Bjerrum plot (Andersen, 2002). Additionally, forest coverage is relatively low in the central region. Forest land is the largest reservoir of vegetation carbon and soil litter carbon (Dixon et al., 1994); the high respiration rate of soil litter results in a high DIC concentration in the adjacent headwater stream (Corson-Rikert et al., 2016; Rasilo et al., 2017; Schindler \& Krabbenhoft, 1998; Triska et al., 1993) and hence, high $\mathrm{CO}_{2}$ degassing.

In the first half of the twentieth century, our DLEM simulation revealed that terrestrial carbon loading and total carbon export both decreased by $\sim 25 \%$; in contrast, between the 1960 s and 2000 s terrestrial carbon loading increased by $42 \%$ while riverine carbon exports increased by $57 \%$. The large changes in carbon export since the 1960s is largely due to the devastating drought in that region which resulted in very low discharge and terrestrial carbon loading. Specifically, discharge is a major factor controlling changes in DIC export in the DLEM; simulated concentrations of DIC (and DOC and POC) in the DLEM did not show abrupt changes during that period (Figure 6). We observed a significant increase in DIC export from the watersheds of Chesapeake Bay and Delaware Bay. However, the $\mathrm{CO}_{2}$ emission does not show significant trends, which is consistent with the temporal patterns of DIC concentrations (Figure 6).

This study suggested that half of the terrestrial carbon loading was exported to the coast of the CBW and the DBW, which is consistent with a previous global data synthesis (Cole et al., 2007). However, the level of $\mathrm{CO}_{2}$ degassing is much lower than that of a recent global level synthesis ( 75\%-80\%) (Drake et al., 2018). The lower evasion/retention estimated here is likely due to the specific environmental condition of the study region, such as temperate climate and high $\mathrm{pH}$ level. A global level data-model intercomparison is clearly needed for improving our predictive understanding of river carbon cycling (Regnier et al., 2013). 


\subsection{Underlying Controls on Riverine Carbon Export}

Humans have substantially changed the magnitude and spatial pattern of carbon fluxes at the global level (Regnier et al., 2013). In this study, climate variability explains most of the interdecadal variability of river flow discharge and the resultant riverine carbon fluxes (Figures 4-9). Changes in the net primary productivity of plants in response to the elevated air temperature and precipitation (Figure 4), in turn, affect plant and soil carbon pools (Pan et al., 2014, 2015; Tian et al., 2011, 2012). We observed remarkable increases in the net primary production and soil respiration (Figure S4), which directly affects terrestrial carbon loading (Figure 7) and riverine carbon fluxes. Similar to the climate impact, the increased N inputs (including deposition, $\mathrm{N}$ fertilizer, and manure N), which alleviate the vegetation N limitation (Vitousek \& Howarth, 1991), contribute to increased primary production and soil carbon pools (Figure 5). On the contrary, land conversion from forest to cropland significantly decreased the soil carbon pool and the associated carbon fluxes of all species (Figure 5).

DIC fluxes predicted by the DLEM decreased from the 1900s to the 1960s, but the DIC exports of the 2000s returned to the level of 1,900 , which is supported by a recent review suggesting that DIC fluxes have returned to their preindustrial level (Raymond \& Hamilton, 2018). However, this review could not attribute the contribution of the environmental factors to the variability of DIC fluxes. Certainly, the DIC export increase since the 1960s is primarily due to increased precipitation. For example, increased precipitation could wash more carbon (DOC, POC, and DIC) from the land surface to rivers (Supplementary Methods), which directly drives a large temporal gradient of DIC export. Further, the increase in precipitation makes more water available for plant growth and helps the accumulation of organic matter in soil which, in turn, indirectly stimulates soil respiration and the resultant DIC loading (Figure S4). Additionally, the increased precipitation provided a wetter soil moisture condition which substantially stimulated the decomposition rate of soil organic carbon (Supplementary Methods). This finding is also supported by field measurements showing significant changes in DIC fluxes in terms of hydrological response (Johnson et al., 2006).

The modeled lateral POC export fluxes did not increase significantly over the past century despite substantial changes in climate and land use. POC erosion from land is strongly correlated with soil erosion, which was calculated by the Modified Universal Soil Loss Equation model (Williams \& Berndt, 1977). In theory, increased precipitation would result in a significant increase in POC erosion. However, several factors offset this precipitation effect. One is the large area of land conversion from cropland to forests (Figure 4). Cropland is recognized as a hotspot of soil erosion, while the soil erosion of natural forest is much lower. Additionally, the increase in organic matter content only slightly increased the POC loading rate. Although the percentage of organic matter per eroded soil increased, the high organic matter content inhibited the erodibility of soils.

\subsection{Uncertainty and Future Research}

Though the model presented here substantially improves the representation of processes relevant to aquatic carbon cycling in the terrestrial system with respect to our earlier DLEM version described in the work of Tian, Yang, et al. (2015), uncertainties remain, which motivate future research in five main areas. First, the DLEM cannot simulate water $\mathrm{pH}$ dynamics due to the lack of observational data, especially in the headwater streams. The boundary conditions of river water $\mathrm{pH}$ ( $\mathrm{pH}$ of groundwater or surface runoff) and the mechanisms controlling water $\mathrm{pH}$ are not clear. Second, the traditional way to calculate the riverine $\mathrm{CO}_{2}$ concentration, which we have adopted, greatly overestimates $\mathrm{CO}_{2}$ degassing in organic-rich freshwaters (Abril et al., 2015). Third, systematic observations and experimental analysis about the gas transfer velocity and the processes within hyporheic zones need to be conducted in the future (Corson-Rikert et al., 2016; Findlay et al., 1993; Schindler \& Krabbenhoft, 1998; Triska et al., 1993). Fourth, we do not consider river $\mathrm{CO}_{2}$ uptake by algae, POC consumption by aquatic species, and organic matter resuspension from the bottom sediment. Fifth, this modeling study simplifies the river routing algorithm without considering the processes within small lakes or reservoirs. Small lakes or ponds do not clearly show an obvious linkage to river networks, and the residence time of small ponds is hard to obtain on a large scale. Finally, the surface area is the most pivotal factor controlling $\mathrm{CO}_{2}$ degassing, but the dynamics of water surface area in headwater streams remains largely uncertain (Allen \& Pavelsky, 2018; Raymond et al., 2013; Wollheim, 2016). 
Constraining the fate of lateral carbon fluxes and greenhouse gas emissions in headwater streams has been challenging and, so far, is incomplete. It is critical to continue developing parameterizations to scale up small rivers to regional and global levels. Carbon dynamics at the riparian and hyporheic zone are determined by complex biophysical and biogeochemical processes with substantial spatial and temporal variations, such as physical erosion, river stage and flow velocity, water temperature, oxygen concentration, and microbial types (Battin et al., 2007; Butman et al., 2016). Therefore, it is essential to improve the understanding of subsurface carbon lateral transport and the associated biogeochemical processes, as well as model development based on the improved understanding, for future study. Lastly, future research should consider how to couple lake or reservoir routing into water transport models using improved lake/reservoir input data sets.

\section{Conclusions}

In this study, we incorporated a scale-adaptive water transport module within our land ecosystem model to investigate biogeochemical processes within small headwater streams as well as higher order streams and to examine how lateral DOC, POC, and DIC fluxes and $\mathrm{CO}_{2}$ degassing have changed over the past century. The results of this study indicate that DOC exports in both the Chesapeake and DBWs showed a largely increasing trend after the 1960s due to climate variability and increased nitrogen inputs, while land use conversion from cropland to forest dampened this increasing trend. The export of DIC showed a similar temporal pattern, mainly due to climate (temperature and precipitation) variability and increasing atmospheric $\mathrm{CO}_{2} \mathrm{Con}$ centrations. The lateral export of POC did not show a significant trend over the past century, since increases in export due to land conversion largely canceled out the decreases due to climate variability. Riverine $\mathrm{CO}_{2}$ degassing accounted for $40 \%$ of the terrestrial carbon loading and showed small decreasing trends throughout much of the watersheds. The enhanced plant productivity increased the soil organic carbon content and hence, the soil respiration, which, in turn, resulted in significant change in terrestrial carbon loading and riverine carbon fluxes. It should be noted that although the DLEM provides well-validated results to estimate the riverine carbon budget, the magnitude, human footprint, and spatial and temporal patterns of vertical and lateral carbon fluxes are still associated with considerable uncertainties due to the difficulties in measuring these fluxes on these scales and assumptions and other uncertainties in the model structure and parameterization. More advanced tools, including data assimilation, are needed to help us better understand and predict the global/regional carbon cycle and its feedback on climate change (Ciais et al., 2008).

\section{Data Availability Statement}

Model results and data used in this study are archived and publicly available in the Auburn University (AUrora) archive at https://auburn.box.com/v/MABriverineCfluxes.

Acknowledgments

This study is the results of research funded in part by NASA Interdisciplinary Science Program (award numbers: NNX11AD47G; NNX14AF93G), NOAA National Centers for Coastal Ocean Science (award number: NA16NOS4780207).

\section{References}

Abril, G., Bouillon, S., Darchambeau, F., Teodoru, C. R., Marwick, T. R., Tamooh, F., et al. (2015). Technical note: Large overestimation of $\mathrm{pCO}_{2}$ calculated from $\mathrm{pH}$ and alkalinity in acidic, organic-rich freshwaters. Biogeosciences, 12(1), 67-78. https://doi.org/10.5194/ bg-12-67-2015

Allen, G. H., \& Pavelsky, T. M. (2018). Global extent of rivers and streams. Science, 361(6402), 585-588. https://doi.org/10.1126/science. aat0636

Allen, G. H., Pavelsky, T. M., Barefoot, E. A., Lamb, M. P., Butman, D., Tashie, A., \& Gleason, C. J. (2018). Similarity of stream width distributions across headwater systems. Nature Communications, 9(1), 610. https://doi.org/10.1038/s41467-018-02991-w

Andersen, C. B. (2002). Understanding carbonate equilibria by measuring alkalinity in experimental and natural systems. Journal of Geoscience Education, 50(4), 389-403. https://doi.org/10.5408/1089-9995-50.4.389

Argerich, A., Haggerty, R., Johnson, S. L., Wondzell, S. M., Dosch, N., Corson-Rikert, H., et al. (2016). Comprehensive multiyear carbon budget of a temperate headwater stream. Journal of Geophysical Research: Biogeosciences, 121(5), 1306-1315. https://doi. org/10.1002/2015JG003050

Asabere, S. B., Zeppenfeld, T., Nketia, K. A., \& Sauer, D. (2018). Urbanization leads to increases in pH, carbonate and soil organic matter stocks of arable soils of Kumasi, Ghana (West Africa). Frontiers in Environmental Science, 6, 119. https://doi.org/10.3389/ fenvs.2018.00119

Battin, T. J., Luyssaert, S., Kaplan, L. A., Aufdenkampe, A. K., Richter, A., \& Tranvik, L. J. (2009). The boundless carbon cycle. Nature Geoscience, 2(9), 598. https://doi.org/10.1038/ngeo618

Battin, T. J., Sloan, W. T., Kjelleberg, S., Daims, H., Head, I. M., Curtis, T. P., \& Eberl, L. (2007). Microbial landscapes: New paths to biofilm research. Nature Reviews Microbiology, 5(1), 76. https://doi.org/10.1038/nrmicro1556

Bauer, J. E., Cai, W.-J., Raymond, P. A., Bianchi, T. S., Hopkinson, C. S., \& Regnier, P. A. G. (2013). The changing carbon cycle of the coastal ocean. Nature, 504(7478), 61. https://doi.org/10.1038/nature12857 
Beckman, N. D., \& Wohl, E. (2014). Carbon storage in mountainous headwater streams: The role of old-growth forest and logjams. Water Resources Research, 50(3), 2376-2393. https://doi.org/10.1002/2013wr014167

Butman, D., \& Raymond, P. A. (2011). Significant efflux of carbon dioxide from streams and rivers in the United States. Nature Geoscience, 4(12), 839. https://doi.org/10.1038/ngeo1294

Butman, D., Stackpoole, S., Stets, E., McDonald, C. P., Clow, D. W., \& Striegl, R. G. (2016). Aquatic carbon cycling in the conterminous United States and implications for terrestrial carbon accounting. Proceedings of the National Academy of Sciences of the United States of America, 113(1), 58-63. https://doi.org/10.1073/pnas.1512651112

Chapra, S. C. (2008). Surface water-quality modeling. Waveland press.

Chow, V. T. (1964). Handbook of applied hydrology. Section, 8, 8-61.

Ciais, P., Borges, A. V., Abril, G., Meybeck, M., Folberth, G., Hauglustaine, D., \& Janssens, I. A. (2008). The impact of lateral carbon fluxes on the European carbon balance. Biogeosciences, 5(5), 1259-1271. https://doi.org/10.5194/bg-5-1259-2008

Coe, M. T. (1998). A linked global model of terrestrial hydrologic processes: Simulation of modern rivers, lakes, and wetlands. Journal of Geophysical Research, 103(D8), 8885-8899. https://doi.org/10.1029/98JD00347

Cole, J. J., Prairie, Y. T., Caraco, N. F., McDowell, W. H., Tranvik, L. J., Striegl, R. G., et al. (2007). Plumbing the global carbon cycle: Integrating inland waters into the terrestrial carbon budget. Ecosystems, 10(1), 172-185. https://doi.org/10.1007/s10021-006-9013-8

Corson-Rikert, H. A., Wondzell, S. M., Haggerty, R., \& Santelmann, M. V. (2016). Carbon dynamics in the hyporheic zone of a headwater mountain stream in the Cascade Mountains, Oregon. Water Resources Research, 52(10), 7556-7576.

Daly, C., Halbleib, M., Smith, J. I., Gibson, W. P., Doggett, M. K., Taylor, G. H., et al. (2008). Physiographically sensitive mapping of climatological temperature and precipitation across the conterminous United States. International Journal of Climatology, 28(15), 2031-2064. https://doi.org/10.1002/joc.1688

Dick, J. J., Tetzlaff, D., Birkel, C., \& Soulsby, C. (2015). Modeling landscape controls on dissolved organic carbon sources and fluxes to streams. Biogeochemistry, 122(2-3), 361-374. https://doi.org/10.1007/s10533-014-0046-3

Dixon, R. K., Solomon, A. M., Brown, S., Houghton, R. A., Trexier, M. C., \& Wisniewski, J. (1994). Carbon pools and flux of global forest ecosystems. Science, 263(5144), 185-190. https://doi.org/10.1126/science.263.5144.185

Drake, T. W., Raymond, P. A., \& Spencer, R. G. M. (2018). Terrestrial carbon inputs to inland waters: A current synthesis of estimates and uncertainty. Limnology \& Oceanography, 3(3), 132-142. https://doi.org/10.1002/lol2.10055

Earth Resources Observation And Science Center. (2017). Global topographic 30 arc-second hydrologic digital elevation model $1 \mathrm{~km}$ [Data set]. U.S. Geological Survey. https://doi.org/10.5066/F77P8WN0

Findlay, S. E. (2005). Increased carbon transport in the Hudson River: Unexpected consequence of nitrogen deposition? Frontiers in Ecology and the Environment, 3(3), 133-137. https://doi.org/10.1890/1540-9295(2005)003[0133:ictith]2.0.co;2

Findlay, S., Strayer, D., Goumbala, C., \& Gould, K. (1993). Metabolism of streamwater dissolved organic carbon in the shallow hyporheic zone. Limnology \& Oceanography, 38(7), 1493-1499. https://doi.org/10.4319/lo.1993.38.7.1493

Georghiades, A. S. (2003). Incorporating the torrance and sparrow model of reflectance in uncalibrated photometric stereo. In Proceedings Ninth IEEE International Conference on Computer Vision (Vol. 3, pp. 816-823).

Getirana, A. C. V., Boone, A., Yamazaki, D., Decharme, B., Papa, F., \& Mognard, N. (2012). The Hydrological Modeling and Analysis Platform (HyMAP): Evaluation in the Amazon Basin. Journal of Hydrometeorology, 13(6), 1641-1665. https://doi.org/10.1175/ JHM-D-12-021.1

Harrison, J. A., Maranger, R. J., Alexander, R. B., Giblin, A. E., Jacinthe, P.-A., Mayorga, E., et al. (2009). The regional and global significance of nitrogen removal in lakes and reservoirs. Biogeochemistry, 93(1-2), 143-157. https://doi.org/10.1007/s10533-008-9272-x

Hartmann, J., Lauerwald, R., \& Moosdorf, N. (2019). GLORICH - Global river chemistry database, supplement to: Hartmann, Jens; Lauerwald, Ronny; Moosdorf, Nils (2014): A brief overview of the GLObal RIver Chemistry Database, GLORICH. Procedia Earth and Planetary Science, 10, 23-27. [Application/zip]. PANGAEA - Data Publisher for Earth \& Environmental Science. https://doi.org/10.1594/ PANGAEA. 902360

Hastie, A., Lauerwald, R., Ciais, P., \& Regnier, P. (2019). Aquatic carbon fluxes dampen the overall variation of net ecosystem productivity in the Amazon basin: An analysis of the interannual variability in the boundless carbon cycle. Global Change Biology, 25(6), 2094-2111.

He, Y., Wang, X., Chen, H., Yuan, X., Wu, N., Zhang, Y., et al. (2017). Effect of watershed urbanization on $\mathrm{N}_{2} \mathrm{O}$ emissions from the Chongqing metropolitan river network, China. Atmospheric Environment, 171, 70-81. https://doi.org/10.1016/j.atmosenv.2017.09.043

Homer, C., Dewitz, J., Yang, L., Jin, S., Danielson, P., Xian, G., et al. (2015). Completion of the 2011 National Land Cover Database for the conterminous United States - representing a decade of land cover change information. Photogrammetric Engineering \& Remote Sensing, $81(5), 345-354$.

Houghton, R. A. (2010). How well do we know the flux of CO2 from land-use change? Tellus B: Chemical and Physical Meteorology, 62(5), 337-351. https://doi.org/10.1111/j.1600-0889.2010.00473.x

Isaak, D. J., Young, M. K., Luce, C. H., Hostetler, S. W., Wenger, S. J., Peterson, E. E., et al. (2016). Slow climate velocities of mountain streams portend their role as refugia for cold-water biodiversity. Proceedings of the National Academy of Sciences of the United States of America, 113(16), 4374-4379. https://doi.org/10.1073/pnas.1522429113

Jantz, P., Goetz, S., \& Jantz, C. (2005). Urbanization and the loss of resource lands in the Chesapeake Bay watershed. Environmental Management, 36(6), 808-825. https://doi.org/10.1007/s00267-004-0315-3

Johnson, M. S., Lehmann, J., Couto, E. G., Filho, J. P. N., \& Riha, S. J. (2006). DOC and DIC in flowpaths of Amazonian headwater catchments with hydrologically contrasting soils. Biogeochemistry, 81(1), 45-57. https://doi.org/10.1007/s10533-006-9029-3

Kunkel, K. E., Stevens, L. E., Stevens, S. E., Sun, L., Janssen, E., Wuebbles, D., et al. (2013). Regional climate trends and scenarios for the US National Climate Assessment. Part 1. Climate of the Northeast US NOAA Technical Report NESDIS 142-1. In National Oceanic and Atmospheric Administration, National Environmental Satellite, Data, and Information Service (pp. 87).

Laruelle, G. G., Goossens, N., Arndt, S., Cai, W.-J., Regnier, P., \& Regnier, P. (2017). Air-water $\mathrm{CO}_{2}$ evasion from US East Coast estuaries. Biogeosciences, 14(9), 2441-2468. https://doi.org/10.5194/bg-14-2441-2017

Laruelle, G. G., Lauerwald, R., Rotschi, J., Raymond, P. A., Hartmann, J., \& Regnier, P. (2015). Seasonal response of air-water $\mathrm{CO}_{2}$ exchange along the land-ocean aquatic continuum of the northeast North American coast. Biogeosciences, 12(5), 1447-1458. https://doi. org/10.5194/bg-12-1447-2015

Laudon, H., Buttle, J., Carey, S. K., McDonnell, J., McGuire, K., Seibert, J., et al. (2012). Cross-regional prediction of long-term trajectory of stream water DOC response to climate change: Cross-regional prediction of DOC. Geophysical Research Letters, 39(18). https://doi.org/10.1029/2012GL053033 
Lehner, B., Liermann, C. R., Revenga, C., Vörösmarty, C., Fekete, B., Crouzet, P., et al. (2011). High-resolution mapping of the world's reservoirs and dams for sustainable river-flow management. Frontiers in Ecology and the Environment, 9(9), 494-502. https://doi. org/10.1890/100125

Li, H., Leung, L. R., Getirana, A., Huang, M., Wu, H., Xu, Y., et al. (2015). Evaluating global streamflow simulations by a physically based routing model coupled with the community land model. Journal of Hydrometeorology, 16(2), 948-971. https://doi.org/10.1175/ JHM-D-14-0079.1

Li, H., Wigmosta, M. S., Wu, H., Huang, M., Ke, Y., Coleman, A. M., \& Leung, L. R. (2013). A physically based runoff routing model for land surface and earth system models. Journal of Hydrometeorology, 14(3), 808-828. https://doi.org/10.1175/JHM-D-12-015.1

Liu, M., \& Tian, H. (2010). China's land cover and land use change from 1700 to 2005: Estimations from high-resolution satellite data and historical archives. Global Biogeochemical Cycles, 24(3). https://doi.org/10.1029/2009gb003687

Liu, M., Tian, H., Yang, Q., Yang, J., Song, X., Lohrenz, S. E., \& Cai, W.-J. (2013). Long-term trends in evapotranspiration and runoff over the drainage basins of the Gulf of Mexico during 1901-2008. Water Resources Research, 49(4), 1988-2012. https://doi.org/10.1002/ wrcr.20180

Marescaux, A., Thieu, V., Gypens, N., Silvestre, M., \& Garnier, J. (2020). Modeling inorganic carbon dynamics in the Seine River continuum in France. Hydrology and Earth System Sciences, 24, 2379-2398. https://doi.org/10.5194/hess-24-2379-2020

McClain, M. E., Boyer, E. W., Dent, C. L., Gergel, S. E., Grimm, N. B., Groffman, P. M., et al. (2003). Biogeochemical hot spots and hot moments at the interface of terrestrial and aquatic ecosystems. Ecosystems, 6(4), 301-312. https://doi.org/10.1007/s10021-003-0161-9

McDonald, C. P., Stets, E. G., Striegl, R. G., \& Butman, D. (2013). Inorganic carbon loading as a primary driver of dissolved carbon dioxide concentrations in the lakes and reservoirs of the contiguous United States. Global Biogeochemical Cycles, 27(2), 285-295. https://doi. org/10.1002/gbc.20032

Mohseni, O., Erickson, T. R., \& Stefan, H. G. (1999). Sensitivity of stream temperatures in the United States to air temperatures projected under a global warming scenario. Water Resources Research, 35(12), 3723-3733. https://doi.org/10.1029/1999wr900193

Mohseni, O., Stefan, H. G., \& Erickson, T. R. (1998). A nonlinear regression model for weekly stream temperatures. Water Resources Research, 34(10), 2685-2692. https://doi.org/10.1029/98WR01877

Nash, J. E., \& Sutcliffe, J. V. (1970). River flow forecasting through conceptual models part I - a discussion of principles. Journal of Hydrology, 10(3), 282-290. https://doi.org/10.1016/0022-1694(70)90255-6

Naylor, L. M., \& Schmidt, E. J. (1986). Agricultural Use of Wood Ash as a Fertilizer and Liming Material (Vol. 69, pp. 10). Tappi.

Noacco, V., Wagener, T., Worrall, F., Burt, T. P., \& Howden, N. J. K. (2017). Human impact on long-term organic carbon export to rivers. Journal of Geophysical Research: Biogeosciences, 122(4), 947-965. https://doi.org/10.1002/2016jg003614

Pan, S., Bian, Z., Tian, H., Yao, Y., Najjar, R. G., Friedrichs, M. A. M., et al. (2021). Impacts of Multiple Environmental Changes on Long-term Nitrogen Loading from the Chesapeake Bay Watershed. Journal of Geophysical Research: Biogeosciences, https://doi. org/10.1029/2020jg005826

Pan, S., Tian, H., Dangal, S. R. S., Ouyang, Z., Lu, C., Yang, J., et al. (2015). Impacts of climate variability and extremes on global net primary production in the first decade of the 21st century. Journal of Geographical Sciences, 25(9), 1027-1044. https://doi.org/10.1007/ s11442-015-1217-4

Pan, S., Tian, H., Dangal, S. R. S., Zhang, C., Yang, J., Tao, B., et al. (2014). Complex spatiotemporal responses of global terrestrial primary production to climate change and increasing atmospheric $\mathrm{CO}_{2}$ in the 21st century. PloS One, 9(11), e112810. https://doi.org/10.1371/ journal.pone.0112810

Pastor, J., Solin, J., Bridgham, S. D., Updegraff, K., Harth, C., Weishampel, P., \& Dewey, B. (2003). Global warming and the export of dissolved organic carbon from boreal peatlands. Oikos, 100(2), 380-386. https://doi.org/10.1034/j.1600-0706.2003.11774.x

Rasilo, T., Hutchins, R. H. S., Ruiz-González, C., \& del Giorgio, P. A. (2017). Transport and transformation of soil-derived $\mathrm{CO}_{2}$, $\mathrm{CH}_{4}$ and DOC sustain $\mathrm{CO}_{2}$ supersaturation in small boreal streams. The Science of the Total Environment, 579, 902-912. https://doi.org/10.1016/j. scitotenv.2016.10.187

Raymond, P. A., \& Hamilton, S. K. (2018). Anthropogenic influences on riverine fluxes of dissolved inorganic carbon to the oceans. Limnology \& Oceanography, 3(3), 143-155. https://doi.org/10.1002/lol2.10069

Raymond, P. A., Hartmann, J., Lauerwald, R., Sobek, S., McDonald, C., Hoover, M., et al. (2013). Global carbon dioxide emissions from inland waters. Nature, 503(7476), 355-359. https://doi.org/10.1038/nature12760

Raymond, P. A., \& Oh, N.-H. (2007). An empirical study of climatic controls on riverine C export from three major U.S. watersheds. Global Biogeochemical Cycles, 21(2). https://doi.org/10.1029/2006GB002783

Raymond, P. A., Zappa, C. J., Butman, D., Bott, T. L., Potter, J., Mulholland, P., et al. (2012). Scaling the gas transfer velocity and hydraulic geometry in streams and small rivers. Limnology \& Oceanography, 2(1), 41-53. https://doi.org/10.1215/21573689-1597669

Regnier, P., Friedlingstein, P., Ciais, P., Mackenzie, F. T., Gruber, N., Janssens, I. A., et al. (2013). Anthropogenic perturbation of the carbon fluxes from land to ocean. Nature Geoscience, 6(8), 597. https://doi.org/10.1038/ngeo1830

Regnier, P., Lauerwald, R., \& Ciais, P. (2014). Carbon Leakage through the terrestrial-aquatic interface: Implications for the Anthropogenic $\mathrm{CO}_{2}$ Budget. Procedia Earth and Planetary Science, 10, 319-324. https://doi.org/10.1016/j.proeps.2014.08.025

Ren, W., Tian, H., Tao, B., Yang, J., Pan, S., Cai, W. J., et al. (2015). Large increase in dissolved inorganic carbon flux from the Mississippi River to Gulf of Mexico due to climatic and anthropogenic changes over the 21st century. Journal of Geophysical Research: Biogeosciences, 120(4), 724-736. https://doi.org/10.1002/2014JG002761

Runkel, R. L., Crawford, C. G., \& Cohn, T. A. (2004). Load Estimator (LOADEST): A FORTRAN program for estimating constituent loads in streams and rivers.

Sander, R. (2015). Compilation of Henry's law constants (version 4.0) for water as solvent. Atmospheric Chemistry and Physics, 15(8), 4399-4981. https://doi.org/10.5194/acp-15-4399-2015

Schindler, J. E., \& Krabbenhoft, D. P. (1998). The hyporheic zone as a source of dissolved organic carbon and carbon gases to a temperate forested stream. Biogeochemistry, 43(2), 157-174. https://doi.org/10.1023/a:1006005311257

Schulte, J. A., Najjar, R. G., \& Lee, S. (2017). Salinity and streamflow variability in the Mid-Atlantic region of the United States and its relationship with large-scale atmospheric circulation patterns. Journal of Hydrology, 550, 65-79. https://doi.org/10.1016/j. jhydrol.2017.03.064

Seager, R., Pederson, N., Kushnir, Y., Nakamura, J., \& Jurburg, S. (2012). The 1960s drought and the subsequent shift to a wetter climate in the Catskill mountains region of the New York City watershed. Journal of Climate, 25(19), 6721-6742. https://doi.org/10.1175/jcli-d-11-00518.1 
Seitzinger, S. P., Harrison, J. A., Dumont, E., Beusen, A. H. W., \& Bouwman, A. F. (2005). Sources and delivery of carbon, nitrogen, and phosphorus to the coastal zone: An overview of Global Nutrient Export from Watersheds (NEWS) models and their application: Global export of C, N, and P to coastal systems. Global Biogeochemical Cycles, 19(4). https://doi.org/10.1029/2005GB002606

Still, C. J., Berry, J. A., Collatz, G. J., \& DeFries, R. S. (2003). Global distribution of $\mathrm{C}_{3}$ and $\mathrm{C}_{4}$ vegetation: Carbon cycle implications. Global Biogeochemical Cycles, 17(1), 6-1-6-14. https://doi.org/10.1029/2001gb001807

Tao, B., Tian, H., Ren, W., Yang, J., Yang, Q., He, R., et al. (2014). Increasing Mississippi river discharge throughout the 21st century influenced by changes in climate, land use, and atmospheric $\mathrm{CO}_{2}$. Geophysical Research Letters, 41(14), 4978-4986. https://doi. $\operatorname{org} / 10.1002 / 2014 \mathrm{GL} 060361$

Tarboton, D. G. (1997). A new method for the determination of flow directions and upslope areas in grid digital elevation models. Water Resources Research, 33(2), 309-319. https://doi.org/10.1029/96wr03137

Thomann, R. V., \& Mueller, J. A. (1987). Principles of surface water quality modeling and control. Harper \& Row Publishers. Retrieved from https://tamug-ir.tdl.org/handle/1969.3/24446

Thornton, P. E., \& Rosenbloom, N. A. (2005). Ecosystem model spin-up: Estimating steady state conditions in a coupled terrestrial carbon and nitrogen cycle model. Ecological Modelling, 189(1-2), 25-48. https://doi.org/10.1016/j.ecolmodel.2005.04.008

Tian, H., Chen, G., Zhang, C., Liu, M., Sun, G., Chappelka, A., et al. (2012). Century-scale responses of ecosystem carbon storage and flux to multiple environmental changes in the southern United States. Ecosystems, 15(4), 674-694. https://doi.org/10.1007/s10021-012-9539-x

Tian, H., Lu, C., Chen, G., Xu, X., Liu, M., Ren, W., et al. (2011). Climate and land use controls over terrestrial water use efficiency in monsoon Asia. Ecohydrol., 4(2), 322-340. https://doi.org/10.1002/eco.216

Tian, H., Ren, W., Yang, J., Tao, B., Cai, W. J., Lohrenz, S. E., et al. (2015). Climate extremes dominating seasonal and interannual variations in carbon export from the Mississippi River Basin. Global Biogeochemical Cycles, 29(9), 1333-1347. https://doi.org/10.1002/2014GB005068

Tian, H., Yang, J., Lu, C., Xu, R., Canadell, J. G., Jackson, R. B., et al. (2018). The global $\mathrm{N}_{2} \mathrm{O}$ model intercomparison project. Bulletin of the American Meteorological Society, 99(6), 1231-1251. https://doi.org/10.1175/BAMS-D-17-0212.1

Tian, H., Yang, Q., Najjar, R. G., Ren, W., Friedrichs, M. A. M., Hopkinson, C. S., \& Pan, S. (2015). Anthropogenic and climatic influences on carbon fluxes from eastern North America to the Atlantic Ocean: A process-based modeling study. Journal of Geophysical Research: Biogeosciences, 120(4), 757-772. https://doi.org/10.1002/2014JG002760

Triska, F. J., Duff, J. H., \& Avanzino, R. J. (1993). The role of water exchange between a stream channel and its hyporheic zone in nitrogen cycling at the terrestrial-aquatic interface. In Nutrient dynamics and retention in land/water ecotones of lowland, temperate lakes and rivers (pp. 167-184). Springer.

Varol, M., \& Li, S. (2017). Biotic and abiotic controls on $\mathrm{CO}_{2}$ partial pressure and $\mathrm{CO}_{2}$ emission in the Tigris River, Turkey. Chemical Geology, 449, 182-193. https://doi.org/10.1016/j.chemgeo.2016.12.003

Vitousek, P. M., \& Howarth, R. W. (1991). Nitrogen limitation on land and in the sea: How can it occur? Biogeochemistry, 13(2), 87-115. https://doi.org/10.1007/bf00002772

Vörösmarty, C. J., Meybeck, M., Fekete, B., Sharma, K., Green, P., \& Syvitski, J. P. M. (2003). Anthropogenic sediment retention: Major global impact from registered river impoundments. Global and Planetary Change, 39(1-2), 169-190. https://doi.org/10.1016/ s0921-8181(03)00023-7

Waisanen, P. J., \& Bliss, N. B. (2002). Changes in population and agricultural land in conterminous United States counties, 1790 to 1997. Global Biogeochemical Cycles, 16(4). https://doi.org/10.1029/2001gb001843

Williams, J. R., \& Berndt, H. D. (1977). Sediment yield prediction based on watershed hydrology. Transactions of the ASAE, 20(6), 1100-1104.

Wohl, E., Dwire, K., Sutfin, N., Polvi, L., \& Bazan, R. (2012). Mechanisms of carbon storage in mountainous headwater rivers. Nature Communications, 3, 1263. https://doi.org/10.1038/ncomms2274

Wollheim, W. M. (2016). From headwaters to rivers to river networks: Scaling in stream ecology. In Stream ecosystems in a changing environment (pp. 349-388). Elsevier.

Wollheim, W. M., Peterson, B. J., Thomas, S. M., Hopkinson, C. H., \& Vörösmarty, C. J. (2008). Dynamics of N removal over annual time periods in a suburban river network. Journal of Geophysical Research: Biogeosciences, 113(G3). https://doi.org/10.1029/2007jg000660

Wu, H., Kimball, J. S., Li, H., Huang, M., Leung, L. R., \& Adler, R. F. (2012). A new global river network database for macroscale hydrologic modeling: Data and analysis note. Water Resources Research, 48(9). https://doi.org/10.1029/2012WR012313

Xu, X. F., Tian, H. Q., Zhang, C., Liu, M. L., Ren, W., Chen, G. S., et al. (2010). Attribution of spatial and temporal variations in terrestrial methane flux over North America. Biogeosciences, 7(11), 3637-3655. https://doi.org/10.5194/bg-7-3637-2010

Yamazaki, D., Kanae, S., Kim, H., \& Oki, T. (2011). A physically based description of floodplain inundation dynamics in a global river routing model: Floodplain inundation dynamics. Water Resources Research, 47(4). https://doi.org/10.1029/2010WR009726

Yamazaki, D., O'Loughlin, F., Trigg, M. A., Miller, Z. F., Pavelsky, T. M., \& Bates, P. D. (2014). Development of the global width database for large rivers. Water Resources Research, 50(4), 3467-3480. https://doi.org/10.1002/2013wr014664

Yang, Q., Tian, H., Friedrichs, M. A. M., Hopkinson, C. S., Lu, C., \& Najjar, R. G. (2015). Increased nitrogen export from eastern North America to the Atlantic Ocean due to climatic and anthropogenic changes during 1901-2008. Journal of Geophysical Research: Biogeosciences, 120(6), 1046-1068. https://doi.org/10.1002/2014jg002763

Yang, Q., Tian, H., Friedrichs, M. A. M., Liu, M., Li, X., \& Yang, J. (2015). Hydrological responses to climate and land-use changes along the North American East Coast: A 110-year historical reconstruction. Journal of the American Water Resources Association, 51(1), 47-67. https://doi.org/10.1111/jawr.12232

Yao, Y., Tian, H., Shi, H., Pan, S., Xu, R., Pan, N., \& Canadell, J. G. (2020). Increased global nitrous oxide emissions from streams and rivers in the Anthropocene. Nature Climate Change, 10(2), 138-142. https://doi.org/10.1038/s41558-019-0665-8

\section{References From the Supporting Information}

Chantigny, M. H. (2003). Dissolved and water-extractable organic matter in soils: A review on the influence of land use and management practices. Geoderma, 113(3-4), 357-380. https://doi.org/10.1016/s0016-7061(02)00370-1

Enríquez, S., Duarte, C. M., \& Sand-Jensen, K. (1993). Patterns in decomposition rates among photosynthetic organisms: The importance of detritus C:N:P content. Oecologia, 94(4), 457-471. https://doi.org/10.1007/bf00566960

Hansen, S., Jensen, H. E., Nielsen, N. E., \& Svendsen, H. (1991). Simulation of nitrogen dynamics in the soil-plant system using the Danish simulation model DAISY, Hydrological interactions between atmosphere. Soil Veg, 204, 185-196. 
Holford, I. C. R., \& Mattingly, G. E. G. (1975). Surface areas of calcium carbonate in soils. Geoderma, 13(3), 247-255. https://doi org/10.1016/0016-7061(75)90021-x

Kätterer, T., Reichstein, M., Andrén, O., \& Lomander, A. (1998). Temperature dependence of organic matter decomposition: A critical review using literature data analyzed with different models. Biology and Fertility of Soils, 27(3), 258-262. https://doi.org/10.1007/ s003740050430

Neff, J. C., \& Asner, G. P. (2001). Dissolved organic carbon in terrestrial ecosystems: Synthesis and a model. Ecosystems, 4(1), 29-48. https:// doi.org/10.1007/s100210000058

Park, J.-H., Kalbitz, K., \& Matzner, E. (2002). Resource control on the production of dissolved organic carbon and nitrogen in a deciduous forest floor. Soil Biology and Biochemistry, 34(6), 813-822. https://doi.org/10.1016/s0038-0717(02)00011-1

Petersen, B. M., Berntsen, J., Hansen, S., \& Jensen, L. S. (2005). CN-SIM - a model for the turnover of soil organic matter. I. Long-term carbon and radiocarbon development. Soil Biology and Biochemistry, 37(2), 359-374. https://doi.org/10.1016/j.soilbio.2004.08.006

Plummer, L. N., Wigley, T. M. L., \& Parkhurst, D. L. (1978). The kinetics of calcite dissolution in $\mathrm{CO}_{2}-$ water systems at 5 degrees to 60 degrees $\mathrm{C}$ and 0.0 to $1.0 \mathrm{~atm} \mathrm{CO}_{2}$. American Journal of Science, 278(2), 179-216. https://doi.org/10.2475/ajs.278.2.179 